\title{
Las asociaciones de cabezas de familia como cauce de representación: un fallido intento de apertura del régimen franquista
}

\author{
Pedro Cobo Pulido
}

\section{INTRODUCCIÓN}

En 1956 los falangistas, en la persona de Arrese, sufrieron una grave derrota al ser rechazados sus proyectos constitucionales. Si no pudieron los falangistas hacerse con el Estado, vía proyectos constitucionales, lo intentaron por otros medios. Uno de ellos, y no el menos importante, fue el de articular un vasto movimiento asociativo familiar, que tuviera capacidad de promocionar, a través de elecciones, a políticos a las más altas esferas del Estado -Ayuntamientos, Diputaciones, Cortes, instituciones dependientes de otros ministerios como el de Sanidad, Hacienda, etc.-. Ese intento por crear un cauce de promoción fue bien acogido por algunos movimientos apostólicos, dependientes de la jerarquía eclesiástica, y por algunos prelados, de tal forma que falangistas y católicos entre 1957 y 1963 colaboraron intensamente en la redacción de un proyecto de Ley de Asociaciones de Cabezas de Familia que permitiría conseguir sus objetivos. Sin embargo, en 1963 el Consejo Nacional del Movimiento presentó un proyecto de ley que impedía de hecho, aunque no de derecho, a los católicos beneficiarse de ese proyecto de ley. A partir de ese momento la oposición de los católicos al proyecto de ley fue, según palabras de la propia Secretaria General, la más eficaz. Oposición que fue apoyada especialmente por los ministerios de Gobernación y Presidencia, aunque estos por distintos motivos que aquellos. Los miembros de la Jerarquía deseaban la ley pero detestaban el monopolio pretendido por la falange; Presidencia y Gobernación no deseaban que ningún tipo de asociaciones, falangistas o no, pudiera promocionara políticos vía elecciones.

El proyecto nunca vio la luz y las asociaciones familiares nunca tuvieron la capacidad política que habían deseado católicos y falangistas. 
La mentalidad autoritaria del Ejecutivo, ayudado por las tendencias totalitarias de los falangistas, abortó lo que podía haber significado una cierta apertura en los estrechos márgenes de la representación política franquista. A partir de 1967, una vez aprobada la LOE, la política española cambió de rumbo y de intensidad. Dejó de hablarse de asociaciones familiares y se propuso abiertamente la necesidad de asociaciones políticas que desembocaron en el Estatuto de Asociaciones Políticas de 1974 que, como es conocido, tampoco dinamizó la vida política debido a la estrechez de miras de los legisladores. Entiendo que ambos propósitos -la fracasada ley de Asociaciones de Cabezas de Familia y el Estatuto de Asociaciones- estaban íntimamente relacionados. El propósito era el mismo: abrir cauces de participación política, y si en el primer caso siempre se aludió a la necesidad de encontrar cauces de expresión para la familia, sin nombrar nunca la creación de asociaciones políticas, no cabe duda de que en la mente de todos las asociaciones familiares no dejaba de ser un eufemismo para, lo que en un futuro se convertiría en partidos políticos. Fue, precisamente, el temor a que las asociaciones familiares se convirtieran en partidos, lo que impidió que llegara a cuajar una labor que duró cerca de una década.

\section{LAS ASOCIACIONES DE CABEZAS DE FAMILIA COMO VIA DE PROMOCIÓN POLIITICA DE FALANGISTAS Y CATÓLICOS}

Las llamadas familias del franquismo, a finales de los años cincuenta y primeros de los sesenta, estaban ya bastante desdibujadas, gaseosas como las denominaría Emilio Romero, por lo que más que como familias políticas se las podría calificar de clientelas al más puro estilo español. Si esas familias expresaron su disconformidad durante la guerra e inmediata posguerra en algunos momentos -caso Hedilla, conflicto de Begoña, carta de procuradores monárquicos en el 43 , etc.- lo cierto es que una vez acabada la conflagración mundial cerraron filas en torno al dictador: de la supervivencia de éste dependía la de cada una de las facciones en las que se apoyaba el régimen. El que la discusión no aflorara a la opinión pública no significaba que la lucha interna por el poder entre carlistas, falangistas, los llamados católicos, o los hombres de Presidencia hubiera cesado. Las disputas no rebasaban las oficinas ministeriales o los pasillos del Pardo, pero allí eran intensas como lo demuestran las numerosas memorias y el estudio de los documentos oficiales de cada uno de los ministerios. 
Los años cincuenta vieron como el cerco internacional se relajaba -acuerdos con los Estados Unidos y el Vaticano- y como la economía repuntaba timidamente -supresión de las cartillas de racionamiento a principios de los cincuenta-. Al disminuir la presión internacional se convertía en menos peligroso el intentar aventuras políticas interiores por parte de algunos que no estaban de acuerdo con su participación en la marcha general del país. Los más descontentos eran los falangistas: ellos, según creían, habían aportado las masas para ganar la cruzada y aunque exteriormente eran omnipresentes en la vida de cualquier español, lo cierto es que el Estado que ellos deseaban habían sido adulterado. No les faltaba parte de razón: Franco los utilizó como claque pero no como guía a seguir para formar un estado fascista.

En 1956 Arrese presentó sus famosos proyectos constitucionales en los que, de aprobarse, la Falange se convertiría en la única fuerza política con posibilidades reales de influir en la sociedad. Los proyectos de corte cercano al totalitarismo fueron rechazados y la Falange, que llevaba cerca de tres años de luna de miel con el franquismo, fue consciente de que nunca se le permitiria una constitución falangista. A pesar de ese fracaso, que provocó la dimisión de Arrese, los falangistas no se desanimaron e intentaron por todos los medios, no sólo no perder poder, sino aumentarlo en la medida de lo posible. Varios fueron los caminos emprendidos con el fin de tener más presencia y peso en la vida pública del país: posiblemente el más importante fue el intento de revitalizar los sindicatos, pero no menos importante fue el intento de aumentar su poder a través de la promoción de las asociaciones familiares dotándolas de poder político.

Los falangistas, frustadas sus esperanzas en un nuevo modelo constitucional, vieron en la promoción política de las asociaciones familiares una brecha a través de la cual podrian llegar a tener el papel predominante que siempre habian deseado tener en la vida pública. Solís, el nuevo Secretario General del Movimiento, y Fraga, el primer Delegado Nacional de Asociaciones, se propusieron como meta un gran movimiento asociativo familiar dependiente totalmente de la Falange. Esas asociaciones deberían tener capacidad de promocionar a sus hombres a todo tipo de organismos públicos, que iban desde las concejalías a los escaños en las Cortes, pasando por todos los institutos nacionales: vivienda, sanidad, etc. Por su parte, la Jerarquía Eclesiástica vio en esas asociaciones familiares la oportunidad para llevar a esos organismos a personas directamente vinculadas a las asociaciones católicas. Ambas instituciones tenian, gracias al decreto de asociaciones de 1941, unas 
bien organizadas asociaciones en las que apoyarse para conseguir los fines propuestos. Con ese fin, ambas se unieron en un primer momento para redactar unos proyectos de ley que pudieran hacer realidad sus ilusiones. Cooperación que fue desde 1957 hasta 1963, momento en el que los falangistas, viendo cercano el momento de la aprobación de la Ley de Asociaciones de Cabezas de Familia, decidieron excluir a las asociaciones católicas de esa ley. A partir de ese momento la Jerarquía eclesiástica sería la oposición más eficaz a los proyectos de la Secretaría General del Movimiento. Finalmente, los proyectos fueron paralizados en las Cortes, y las asociaciones familiares no tuvieron la capacidad política prevista por sus máximos promotores.

\section{EL DECRETO DE ASOCIACIONES DE 1941: ORIGEN DE LAS FRICCIONES EN EL CONTROL POR EL ASOCIACIONISMO}

Al poco tiempo de finalizar la Guerra Civil, y eliminados los partidos políticos que pudiesen ser una rémora para la "reconstrucción Nacional», era también necesario, de acuerdo con la mentalidad autoritaria imperante, controlar las asociaciones dedicadas a actividades culturales, deportivas o de otro tipo. Éstas, al ser una necesidad básica de toda sociedad relativamente desarrollada, no se podían prohibir, pero era necesario «encauzarlas" para que se limitasen a los fines específicos de la asociación y no se convirtiesen, por falta de espacios adecuados, en remedo de los extintos partidos políticos. La ley de asociaciones vigente en ese momento databa de 1887, pero, por su carácter relativamente liberal era necesariamente inservible para los propósitos de los nuevos gobernantes. De esta forma, en 1941 el Ministerio de la Gobernación reguló, mediante Decreto, el derecho de Asociación ${ }^{1}$. Éste declaraba en su preámbulo que:

wera conveniente eliminar de la documentación administrativa todas aquellas [asociaciones] que, aunque no se hayan disuelto expresamente, pueda presumirse que están extinguidas".

Esta norma, como es obvio, estaba encaminada a eliminar a asociaciones constituidas durante la República o tiempos anteriores -que no fueran partidos, ya prohibidos-, y que pudieran tener una orientación izquierdista, republicana o simplemente sospechosa de no ser entusiastas del nuevo Piégimen: ateneos, casas del pueblo, etc.

1 Decreto del Ministerio de la Gobernación de 25 de enero de 1941, regulando el ejercicio del derecho de asociación, BOE de 6 de febrero de 1941. 
Para las nuevas asociaciones que quisieran crearse, se preveía que no podrían constituirse "sin aprobación del Ministerio de la Gobernación" (art. 1.9). Sin embargo, quedaban exceptuadas de este requisito varios tipos de asociaciones, siendo las más significativas para nuestro estudio dos tipos de asociaciones:

"Las asociaciones católicas que se propongan un fin exclusivamente religioso" (art. 1.9, 2.9).

"Las asociaciones sujetas a la Legislación Sindical y a la disciplina de la Falange Española Tradicionalista y de las JONS" (art. 1, 5. ${ }^{2}$ ).

Así, nada más empezar la andadura del nuevo sistema político, se creaban tres jurisdicciones bajo las que estarian sometidas las asociaciones: las dependientes del Ministerio de la Gobernación, las sometidas a la jurisdicción de la SGM, y las impulsadas y dependientes de la Jerarquía Eclesiástica. La base para el conflicto estaba puesta. El tiempo, la ambigüedad legislativa -calculada desde las altas instancias-y la falta de cauces para la expresión política, se encargaría del resto. El enfrentamiento era prácticamente inevitable.

El Decreto de Asociaciones, que tenía, por propia definición, carácter transitorio «hasta tanto no se regule de una manera definitiva en articulaciones de más amplio alcance.." (preámbulo del Decreto), estuvo vigente hasta $1964^{2}$ cuando, por Ley, se regularon las Asociaciones anulándose el Decreto de 1941. El tiempo transcurrido entre una y otra ofrece una idea del temor que tenian las autoridades franquistas a una apertura en este terreno ${ }^{3}$.

A pesar de las restricciones existentes en materia asociativa, la Jerarquía eclesiástica aprovechó la ley de asociaciones de 1941. La principal asociación religiosa existente en España, tanto antes como después de la Guerra Civil, era la Acción Católica (AC). Ésta se nutría fundamentalmente para sus cargos directivos de los hombres de la Asociación Católica Nacional de Propagandistas (ACN de P), tanto es así, que Martín Artajo, miembro de la $A C N$ de $P$, era el presidente de $A C$ antes de ocupar un puesto en el Gobierno en 1945. A partir de ese momento la asociación

2 Ley de 24 de diciembre de 1964, BOE de 28 de diciembre de 1964.

3 Es cierto que en ese largo espacio de tiempo hubo otro un intento de regulación de las Asociaciones: en diciembre de 1945 se envió a las Cortes un Proyecto de Ley de Asociaciones que era más liberal que el de 1941, pero que no llegó a aprobarse (Cfr. PAYNE, S.G., El Régimen de Franco, op. cit., pág. 365). Aparte de este fallido intento, no se reguló legalmente nada más en el terreno asociativo. 
católica fue adquiriendo relevancia y en 1946 el Gobierno permitió la creación de las HOAC, su rama obrera. Además Ecclesia, medio de difusión oficial de la AC, se convirtió desde 1944, gracias a la supresión de la censura previa de las publicaciones de la Igleșia, en un foco de tensiones para el Gobierno 4 . La importancia numérica de la $A C$ fue creciendo con los años, y llegó a tener en los años cincuenta a más de medio millón de militantes 5 . En 1964 se creó la Unión Nacional de Apostolado Seglar (UNAS) con el fin de coordinar el apostolado seglar dependiente de la Jerarquía, llegando a contar, a finales de los sesenta, con más de un centenar de instituciones organizadas en dieciséis grupos, además de poseer 47 radios y numerosos periódicos. Estas cifras, y la enorme influencia de los obispos en la población española, nos proporcionan substancial información acerca de la importancia que podían tener estas asociaciones si encontraban un cauce para promocionar hombres hacia la vida pública.

La fuerza de las asociaciones católicas era reforzada por la mentalidad de "partido único" existente entre muchos líderes católicos. Aunque León XIII durante su pontificado había defendido claramente la licitud de la divergencia en lo opinable, esta forma de entender la política no había llegado a penetrar en la mentalidad de los católicos españoles. Esta falta de permeabilidad a las encíclicas papales se vería reflejada especialmente en la actitud de algunos miembros de la $A C N$ de $P$ al proponerse la unidad política de los católicos.

No se consiguió un partido demócrata-cristiano ${ }^{6}$-ya que el apoyo de la ACN de $\mathrm{P}$ a Franco significaba que buena parte de ésta aceptaba el

4 Cfr. Chuliá, E., La Evolución Silenciosa..., op. cit., pág. 205 y Salgado Araujo, F., Mis Conversaciones Privadas..., op. cit. pág. 265.

5 Tomo los datos de Andrés-Gallego, J., «Entre la Religión y la Política», op. cit., pág. 91.

6 El momento, una vez derrotado el fascismo europeo, parecía propicio para que los hombres de la $\mathrm{ACN}$ de $\mathrm{P}$ consiguieran un giro en la representación política, proponiéndose conseguir la unidad política de todos los catélicos españoles (Ć́r. ANDRÉS-GALLEGO, J., "Entre la Religión y la Política", op. cit., pág. 99-101). Ése sería el propósito con el que llegó Martín Artajo al Gobierno, quien, según Andrés-Gallego intentó trasponer a España el planteamiento político que predominó en Francia a finales del XIX y en Italia en la segunda mitad de los cuarenta con la democracia cristiana (Cfr. ANDRES-Galiego, J., "Entre la Religión y la Política», op. cit., pág. 101),. Y de hecho, algunos democratacristianos italianos vieron en la liegada de la ACN de $P$ al Gobierno como el equivalente italiano a su propia postura (Cfr. ANDRÉs-GaLleGO, J., La Iglesia en la España Contemporánea (1936-1998), Ediciones Encuentro, Madrid, 1999, pág. 81). Si quizá esa interpretación pueda parecer atrevida, sí existen datos del deseo, por parte de Martín Artajo, de impulsar la representatividad del Régimen. Así, en un documento de julio de 1945, el nuevo ministro afirmaba: "Se trata de restablecer en España un régimen representativo sin disimular la autoridad" (en TUSELL, J., Franco y los Católicos. Politica Interior Española entre 1945-1957, Alianza Editorial, Madrid, 1984, pág. 85). 
status quo de una dictadura-, ni tampoco aumentar la representatividad en esos años; pero permanecía intacto el deseo de poder promocionar políticos católicos a través de cauces propios. Por eso, era necesario buscar una vía por donde poder acceder a los organismos representativos. La Ley de Cortes de 1942 había dejado pocas posibilidades; la de Régimen Local de 1945 permitió un pequeñísimo resquicio a través de los concejales del tercio familiar, pero que era inoperante debido a las supeditación de las corporaciones locales a la Administración Central. Sin embargo, el tercio familiar, desarrollándolo convenientemente, podía ser ese trampolín para promocionar hombres salidos de las filas de los "católicos". De esta forma, al igual que la lo había intentado la Falange, parte de las autoridades eclesiásticas propusieron abrir el cauce de las asociaciones familiares que, con el tiempo, se podía convertir, aunque nunca se dijera explícitamente, en un verdadero partido político. Con lo dicho no se quiere afirmar que en la primera mitad de los años sesenta se estuviera buscando la democracia, sino más bien, lo que se pretendía era, manteniendo el estado autoritario y las fuerzas que lo integraban, que se aumentasen los cauces representativos.

Por su parte, la Falange, gracias a los privilegios concedidos tras el Decreto de Unificación y la aprobación de sus Estatutos, fue extendiendo su influencia a todos los niveles de la vida pública: ex-cautivos, juventudes, sección femenina, Vieja Guardía, prensa, etc. y muy especialmente en el terreno sindical. Fue precisamente ese complejo y extenso engranaje, lo que le llevó a tener importantes y constantes detractores. Entre ellos Carrero, quien ya en los primeros años cuarenta criticaba a la Falange a la que veía como una duplicación del Estado, según afirmaba en sendos informes ${ }^{7}$. Aún así, la Falange distaba de ser un partido único al estilo del nazi o del partido comunista de los países más allá del telón de acero. Tenían cientos de miles de afiliados, pero el ascenso a los puestos relevantes en su mayor parte no procedían de sus filas $y$, en muchas ocasiones, el pertenecer a la Falange era un obstáculo para llegar a ellos. Con el fin de paliar esa situación la Secretaria General del Movimiento decidió que era necesario crear un cauce seguro para que sus afiliados pudiesen llegar a ocupar los puestos claves del Estado.

7 Tusell, J., Carrero..., op. cit., pág. 68 y 73 . En la primera se refiere al informe que Carrero envió a Franco con fecha 26-XII-1941, y en la segunda al informe con fecha de 12-V-1942. 


\section{LA S.G.M.Y YEL INICIO DEL MOVIMIENTO ASOCIATIVO FAMILIAR}

\subsection{La creación de la DNA: el punto de partida}

Las asociaciones dependientes de la Falange -ex combatientes, ex cautivos, etc. - a la altura 1957 habían tenido una vida lánguida, siendo utilizadas fundamentalmente para las grandes jornadas conmemorativas, donde los falangistas actuaban como catalizadores del fervor popular. Los dirigentes falangistas después del suicidio político de Arrese en 1956 fueron conscientes de que, por el momento, era imposible hacerse con el Estado por la vía de las Leyes Fundamentales, por lo que era necesario cambiar de estrategia. El camino elegido, aparte del intento de reforzar el sindicalismo, fue el crear asociaciones familiares, controladas por ellos, y dotarlas de verdadera influencia política.

En 1957, a los pocos meses del relevo de Arrese por Solís como Secretario General del Movimiento, se produjo una reestructuración de los Servicios de la SGM, entre las novedades se encontraba la creación de la Delegación Nacional de Asociaciones (DNA) ${ }^{8}$. En el artículo $9 .^{9}$ del Decreto se especificó que una de las principales funciones de la nueva Delegación Nacional era la "creación y funcionamiento de Asociaciones o Entidades de Cabeza de Familia ${ }^{9}$, al objeto de dar expresión concreta al principio doctrinal que considera a la familia como cauce de participación del hombre en las tareas públicas.»

La redacción del artículo era ambigua y en él no se cita la participación política, sino la "participación (...) en las tareas públicas", término amplisimo que se podía aplicar a aquello que se desease según las circunstancias. Lo que sí quedaba de manifiesto en el artículo era, por una parte, que esa participación se debía realizar a través de las asociaciones del Movimiento ya existentes, y por otra que la «familia» concretaría su participación en las tareas públicas a través de las nuevas Asociaciones de Cabezas de Familia, que estaba previsto crear, y que dependerían de la recién creada DNA.

8 Art. 2. ${ }^{\circ}$ del Decreto de 20 de julio de 1957 (SGM). BOE, 27 de julio de 1957. Por la Orden de la SGM, de 30 de junio de 1958, quedarian englobadas en esta DNA los antiguos Servicios relacionados con las Asociaciones: el Servicio de Asociaciones de Antiguos Combatientes, el Servicio de Hermandades de Ex cautivos, Servicio de Asociaciones del Profesorado de Enseñanzas Superiores y Medias, Servicio de Asociaciones de Enseñanza Primaria y el Sindicato Español Universitario (art. 3.9).

9 El subrayado es nuestro. 
El primer Delegado Nacional de Asociaciones fue Fraga, quien renunció a su puesto de subdirector en el Instituto de Estudios Políticos para ocupar el nuevo cargo. Uno de los primeros pasos de Fraga en la DNA, animado por Solís, fue el anuncio de la incorporación de la Asociación de Alféreces Provisionales, una de las más importantes en aquél momento, a esa Delegación Nacional. Sin embargo Fraga pronto fue consciente de la inviabilidad de esas iniciativas: la oposición total de Gobernación, aduciendo éste que las asociaciones dependían de su ministerio, y no de la SGM, malogró las iniciativas del joven político gallego ${ }^{10}$. Esta primera reacción de Gobernación, no fue más que el inicio de una serie de continuos conflictos entre ambos ministerios con respecto al asociacionismo. El motivo era debido, más que a pequeñas susceptibilidades referentes a las competencias, a que el impulso de las asociaciones tenían una clara finalidad política, y de no pequeño alcance, por lo que ambos ministerios pretendieron arrogarse su jurisdicción. Solís 11 lo apuntaba rotundamente en carta dirigida al director del diario Ya en 1968. En ella, negaba que nunca había afirmado que la asociaciones del Movimiento no tuvieran finalidad política, según se afirmaba en un artículo escrito por él en el diario católico:

"Creo que la mejor dialéctica es la de los hechos. A los pocos meses de mi designación como Ministro Secretario General del Movimiento presenté a la aprobación de nuestro Jefe Nacional una modificación de las estructuras de la Secretaría General (..). En él se regulaba a DNA como Organo del Movimiento encargado de canalizar las aspiraciones e inquietudes de los españoles expresadas a través de las Asociaciones. Resalta, por tanto, que ya entonces estaba clara su naturaleza. Toda asociación, agrupación u organización del Movimiento ha de ser, indudablemente, una entidad politica.

Ni Solís ni Fraga consiguieron dotar de verdadera relevancia política a las asociaciones del Movimiento, pero con la creación de la DNA y con el impulso del movimiento asociativo familiar daban un paso más en el número de privilegios con respecto al control del asociacionismo español ${ }^{12}$. La SGM, una vez que se habia asegurado el control de las Asociaciones a través de la Delegación Nacional respectiva, creyó necesario elaborar unos estatutos -con el fin de corroborar que las asociaciones auspiciadas por la DNA no iban a tener otra dependencia que no fuese la de la propia SGM-y un Decreto que regulase las funciones políticas que iban a tener aquellas.

10 Cfr. Benerto, J., La Identidad del Franquismo, op. cit., pág. 120.

11 La carta está fechada el 15 de noviembre de 1968, momento en que se estaba trabajando sobre el tema del Estatuto Orgánico del Movimiento. AGA, Interior, caja 479.

12 La situación de privilegio fue reconocida en por la SGM en 1958 cuando elaboró un Anteproyecto de Ley de Asociaciones -esta Ley no fue aprobada hasta 1964-. En el borrador dice 


\subsection{El Proyecto de Estatuto de Asociaciones del Movimiento} y la oposición del Ministerio de la Gobernación

A finales de 1957 o principios de 1958, la SGM elaboró un Anteproyecto de Estatuto de Asociaciones del Movimiento 13. En el preámbulo de ese Anteproyecto se reconoce la necesidad de dictar las normas estatutarias necesarias para que las asociaciones del Movimiento pudieran desarrollarse debidamente y con plena autonomía:

"...de modo que sin perjuicio de su plena autonomía, sea eficaz su colaboración con el Movimiento y tengan sus aspiraciones y propósitos un canon seguro y eficaz al Gobierno y a las Cortes."

El articulado de los estatutos aseguraba esa «plena autonomía», porque, como bien observaría el Ministerio de la Gobernación ${ }^{14}$, tenían un objetivo patente: las asociaciones del Movimiento sólo y únicamente dependerían de la SGM. De esta forma, la SGM pretendia sustraer a numerosas asociaciones de la férula de Gobernación, lo que, como era de esperar, no agradó mucho a este último ministerio.

La reacción del Ministerio de Gobernación no se hizo esperar y elaboró un documento haciendo observaciones al referido Estatuto ${ }^{15}$. El Departamento dirigido por Alonso Vega, advirtió claramente las intenciones de la SGM y, aunque diplomáticamente le parecieran «dignos de aplauso" los esfuerzos hechos en pro del asociacionismo que darían al Movimiento Nacional «una gran vitalidad», Gobernación entendia que, precisamente por la altura de miras que tenía el Estatuto, era «merecedor de una atención más detenida que la que le correspondería a otro proyecto de disposición de igual rango", ya que al fin y al cabo, entendía Gobernación, Ja DNA «depende de este estatuto".

Gobernación consideró que «lo que más llama la atención» era la insistencia que tenía la SGM en considerar a las Asociaciones sometidas a ese Estatuto, exentas de la legislación ordinaria, es decir, independientes de Gobernación, y veía que si ese Estatuto prosperara se crearian conflictos:

textualmente: «(e)n efecto, el Movimiento tiene, en este momento, una situación privilegiada para sus asociaciones...". La palabra "privilegiada" fue sustituida por "especial" en un segundo documento corrigiendo al primero. Ambos textos se encuentran en AGA, SGM, caja 280.

13 «Estatutos de las Asociaciones del Movimiento». AGA, Interior, caja 2752.

14 «Nota de Gobernación Acerca del Proyecto de Estatuto de Asociaciones del Movimiento', AGA, Interior, caja 2752.

15 «Nota de Gobernación acerca del Proyecto de Estatuto de Asociaciones del Movimientow, AGA, Interior, caja 2752. 
«existirían en España, dos tipos de Asociaciones. Dos legislaciones paralelas, en el mejor de los casos, quizá en muchos puntos opuestas. Dos organismos distintos con autoridad sobre ellas (...) Los conflictos a que a ello puede dar lugar (..) pueden ser graves".

El Estatuto no se aprobó, pero sí se le concedió a la SGM que sus asociaciones sólo se sometieran a su jurisdicción, y no a la de Gobernación. La herida fue cerrada en falso y, por lo tanto, los conflictos continuaron.

\subsection{El Anteproyecto de Decreto de las Asociaciones de Cabezas de Familia dependientes de la SGM}

La SGM pretendía, después de aprobar el Estatuto de las Asociaciones del Movimiento, sancionar un decreto regulando las Asociaciones de Cabeza de Familia 16.

Que los falangistas no habian desistido, a pesar del fracaso de Arrese, en la lucha por ser el único cauce para la promoción política lo demuestra el preámbulo de este Anteproyecto de Asociaciones de Vecinos Cabezas de Familia. En él se recuerda el decreto de Unificación de 1937, en el que se definía al Movimiento Nacional como «una sola entidad», y como «la organización intermedia entre la Sociedad y el Estado", cuya principal misión era la de "comunicar al Estado el aliento del pueblo, y de llevar a éste el pensamiento de aquél». Partiendo de la base de que ese «aliento» se debia hacer a través de los tres tercios joseantonianos, señalaba ese preámbulo que la representación sindical «está ya muy organizada, desde la base de los enlaces sindicales hasta el tercio de representación en las Cortes"; en parecidos términos se refiere el preámbulo con respecto a la representación municipal, pero, por el contrario, considera que la representación familiar no era la adecuada, por lo que era necesario estimularla:

«Por lo que se refiere a la representación familiar, existe ya el tercio representante de los cabezas de familia en los ayuntamientos; pero se estima que se puede perfeccionar su intervención en la vida municipal, a través de las Asociaciones de Vecinos de Familia, que mantengan la articulación permanente de los mismos, no sólo en los períodos electorales, sino en todo momento, facilitando el ejercicio de los deberes y derechos públicos de los interesados, y la tutela de sus intereses de carácter no profesional de modo continuo.»

16 Tomo este dato del documento, «Información Confidencial sobre el Proyecto de Decreto de Asociaciones de Cabezas de Familia", fue elaborado por SGM, AGA, SGM, caja. 60, en donde se sostiene que la elaboración el Estatuto fue previo al Anteproyecto que estamos analizando. 
Es de notar que en ese momento las asociaciones familiares no podian participar en las elecciones, pero se puede percibir que, desde el principio, fue uno de los objetivos prioritarios del movimiento asociativo familiar. Continúa el preámbulo refiriéndose al verdadero objetivo del Anteproyecto: dar amplias facultades a estas asociaciones e intentar proyectarla hacia la vida pública provincial y nacional:

«Estas asociaciones podrán tener además su adecuada proyección en todos aquellos problemas que afecten de modo especial a la familia, como es todo lo relativo a educación, beneficencia, protección de menores, moralidad pública, etc.; y habrá de corresponderles, a medida que se vayan desarrollando, una proyección adecuada en la vida provincial y nacional."

Que el Proyecto no pretendia una mera participación testimonial de las Asociaciones dependientes del Movimiento en el Municipio, sino que, sin lugar a dudas, sus pretensiones iban mucho más allá, lo demuestra una nota manuscrita que antecede a la exposición de motivos del Anteproyecto, muy posiblemente hecha por Solís ${ }^{17}$, en la que se afirma:

res tema tan importante y tan fundamental que debiera ocupar una serie de sesiones de la Junta Política» 18.

La exposición de motivos seguía con un recorrido por la doctrina falangista acerca de la familia, y la importancia de ésta para la vida nacional. También recordaba toda la legislación vigente que hasta ese momento había apoyado al buen desarrollo de la «célula básica de la sociedad», pero señalaba que:

"Sin embargo, parece conveniente dar un mayor grado de institucionalización, a las asociaciones representativas de la familia española; y lograda ésta, una influencia más directa en los órganos centrales del Estado»

El camino era claro; primero, participar en la administración local y, una vez conseguido, llegar a la central. Seguía diciendo la exposición de motivos:

«Para ello ningún cauce más adecuado que el Movimiento Nacional, en el que se integran todas las energías de la Nación, a través de los diversos cauces orgánicos. Así se lograría, al lado de la organización Sindical y de las estructuras municipales, una auténtica realización del principio de la función

17 «Proyecto de Decreto Organizando las Asociaciones de Vecinos Cabezas de Familia, Incorporadas al Movimiento Nacional», AGA, SGM, caja 60. Consta de 6 folios escritos a méquina, en donde no está el Proyecto, sino la exposición de motivos. Antecede a este escrito un folio manuscrito escrito en un papel con el membrete del Consejc de Ministros.

18 Subrayado del original. 
familiar como instrumento de representación, y modo de participar activamente en la cosa pública»

El Proyecto fue estudiado en el ministerio de la Gobernación, en cuyo seno, según un «informe confidencial» de la SGM ${ }^{19}$, hubo disparidad de criterios acerca de su importancia: el Ministro de la Gobernación, apoyado por López Rodó, pensaba que las asociaciones debian ser reguladas por Ley, y que su control correspondía a su ministerio; Blas Tello, Director General de Política Interior, apoyó el Proyecto, «como un caballero, un falangista y un amigo"; finalmente, el Gabinete de Estudios del Ministerio de Gobernación, consideró que no había inconveniente en regular las Asociaciones de Cabezas de Familia por Decreto, pero que, debido a las pocas atribuciones que se les condecía a éstas, serían «inoperantes». No estuvo de acuerdo la SGM con esa calificación y lo expresó taxativamente: «cambiarían de opinión si desde ahora hablásemos de su intervención en la vida municipal o provincial, o de su representación en el Consejo Nacional, etc.»20.

El Decreto no se aprobó inmediatamente, sino que tuvo que esperar a 1963, pero con importantes modificaciones con respecto al que hemos visto, ya que no tendrían ninguna atribución política. Por eso, no es de extrañar las quejas de la SGM, ante lo que primero se les prometía y después se les negaba; y así en el citado informe confidencial de SGM, previendo que se les iba a negar la capacidad política de las asociaciones familiares, se afirmaba:

«debe subrayarse lo extraño de una actitud, que, después de impulsar al Movimiento a tomar el camino de las Asociaciones, al ver el impulso que éstas pueden tomar dentro de su cauce, intenta impedirlo por todos los medios, discutiendo su Estatuto, el Decreto creando las de Cabeza de familia, etc.»

A pesar de la objetividad de las quejas, desde el punto de vista de los falangistas, no se le cerraban de forma definitiva las puertas a sus pretensiones, ya que era a ellos a quien se les había concedido la facultad de crear y fomentar el asociacionismo de los cabezas de familia, y no convenía cortarle del todo sus aspiraciones. Seguía siendo necesario que la Falange, dirigida hábilmente por Franco, siguiera cumpliendo la función de

19 «Información Confidencial sobre el Proyecto de Decreto de Asociaciones de Cabezas de Familia". AGA, SGM, caja. 60. Consta de cuatro folios mecanografiados, hechos en papel con el membrete de la SGM. No tiene fecha ni firma.

20 anformación Confidencial sobre el Proyecto de Decreto de Asociaciones de Cabezas de Familia». AGA, SGM, caja. 60. Consta de cuatro folios mecanografiados, hechos en papel con el membrete de la SGM. No tiene fecha ni firma. 
«claque» en la politica española. Por eso, aunque no se le concedía a la Falange todo lo que ella deseaba quería, sin embargo se le permitió que tutelara todo el movimiento asociativo familiar.

\subsection{Movilización para abrir un cauce para las Asociaciones de Familias: La reorganización de la DNA, la creación del Consejo Nacional de Asociaciones y el I y II Congreso de la Familia Española, etc.}

Si el Estatuto y el Decreto sobre asociaciones de cabezas de familia habían fracasado, no por eso renunciaron a trabajar desde la DNA con el objetivo de dar impulsos a las asociaciones del Movimiento. Con este fin se reorganizó en 1958, poco después de ser creada, la DNA 21, y se convocaron sendos Congresos de la Familia en 1959 y. 1960.

En la Orden de la SGM que reorganizó la DNA se preveía la creación de un Registro de Asociaciones del Movimiento en donde estarían todas las asociaciones que pertenecieran al mismo (art. 5). A la vez, se preveía la creación del Consejo Nacional de Asociaciones que estaria bajo la presidencia del Ministro Secretario: su función sería la coordinación de los problemas comunes de las Asociaciones del Movimiento (art. 7.).

En el mismo mes de junio de 1958, se convocó, por la DNA el I Congreso de la Familia Española, con el fin de «dar a la unidad familiar el realce y la presencia pública que le ha asignado nuestro Movimiento» 22. El temario del Congreso, finalmente celebrado en febrero de 1959, fue, de forma resumida, el siguiente: La familia en la doctrina del Movimiento Nacional; la protección de la familia por el Estado; la familia y la educación nacional; la familia y la moralidad pública; etc. En el Congreso se trataron de todos estos temas y de otros muchos que, como se ve, abarcaban casi todos los aspectos de la vida pública de cualquier ciudadano. Sin embargo, el aspecto más importante era el señalado en la circular extraordinaria: crear un cauce para la representación familiar. $Y$ así parece que lo consideró el Ministerio de la Gobernación, quien, en nota manuscrita, criticó los objetivos del mismo ${ }^{23}$. Consideraba la nota que el Congreso de la

21 BOM núm. 735, del 10 de julio de 1958. BOE 31 de julio de 1958.

22 "Circular Extraordinaria Sobre el I Congreso de la Familia Española" de noviembre de 1958. AGA, Interior, caja 2752.

23 Nota manuscrita, sin fecha y sin firma, cuyo encabezado es: «Los verdaderos objetivos del Congreso de la F.», AGA, Interior, caja 2752, no tiene fecha ni firma, pero por su contenido puede haber poca duda de que fue realizada por personas de Gobernación. 
Familia pretendía "arrogarse el monopolio de la representación política de la Familia creando unas Corporaciones de Derecho Público o sindicatos familiares". Esto estaria en pugna -según este ministerio- con el derecho de libre asociación en su vertiente religiosa -asociaciones católicas de padres de familia- y en su vertiente política, ya que los municipios habían sido considerados como uagrupación de las familias y residentes en un determinado territorio". Ante estas pretensiones, Gobernación propuso unas medidas de actuación recogidas en la misma nota manuscrita. Estas eran: todo lo relativo a la Comisión de Asociaciones y al bien común municipal debería examinado por Gobernación antes de aprobarlas; los estatutos de las asociaciones deberían pasar por su ministerio, a quien competiría la aprobación una vez comprobado si sus fines correspondían a una asociación o al poder público.

Las resoluciones finales del I Congreso ${ }^{24}$, celebrado en febrero de 1959, debido a las presiones recibidas no fueron muy específicas con respecto a las funciones que deberían asumir las Asociaciones de Cabezas de Familia, contentándose con una exposición más bien vaga, pero que dejaba las puertas abiertas para posteriores pasos:

«El Movimiento Nacional promoverá la organización de las Asociaciones de Cabezas de Familia, que comprenderán, entre sus funciones, la de dar cauce a la participación de aquellas en las tareas públicas, principalmente en lo que hace relación a sus fines e intereses"

Con parecidos términos concluía un documento interno que recogía las ideas principales del II Congreso de la Familia Española, celebrado en 196025 .

En 1959, entre los dos Congresos de Familia, y como consecuencia de los acuerdos que se tomaron en el I Congreso de la Familia Española, se creó, por Orden de SGM, un nuevo "Servicio" dentro de la DNA: el de Asociaciones Familiares ${ }^{26}$. Este nuevo Servicio constaría de un Gabinete Técnico que estaría formado por un Jefe de Estudios, un Jefe de Documentación, un Jefe de Información y Publicaciones, y un Jefe de Organización y Actos Públicos (I. art. 4.9). A la vez, se crearon la Secretaría Permanente de los Congresos de Familia, para la que se ponía a su dis-

24 Citado en "Nota Sobre la redacción del Anteproyecto de Ley de Asociaciones Familiares". AGA, SGM, caja 395.

25 “Nota sobre la Redacción del Anteproyecto de Ley de Asociaciones de Cabezas de Familia", AGA, SGM, caja 395.

26 Orden de SGM, 31 de marzo de 1959, por la que se reorganiza el Servicio de Asociaciones. BOM núm. 762, del 10 de abril. y publicado en el BOE, 16 de abril de 1959. 
posición todos los medios de la DNA, un Centro de Estudios y Publicaciones sobre cuestiones familiares, y un Departamento de Información y Asesoramiento de las Familias (II. arts. 1, 2 y 3).

En el mismo BOE que se publicó la reorganización de las Asociaciones familiares se incluyó el Reglamento del Consejo Nacional de Asociaciones 27 creado un año antes. Se definían como sus funciones «la coordinación de los problemas comunes de las asociaciones encuadradas en el Movimiento" (art. 1.9), y se disponía que este organismo funcionaría en Pleno, que se reuniría una vez al año, y en Comisión Permanente, que se reuniría una vez al mes (art. $2 .^{9}$ ).

Como se puede ver, poco a poco, y aunque con muchas trabas, se estaba articulando un organigrama burocrático perfectamente organizado, que apoyado en los presupuestos del Estado, daría una ventaja enorme a la Falange con respecto a sus posibles competidores, en el caso de que las asociaciones familiares pudiesen presentar candidatos a los distintos niveles de la vida pública.

\section{REPRESENTACIÓN FAMILIAR Y EXPECTATIVAS POLITIICAS EN LA «NOTA DE ORIENTACIÓN POLÍTICA» ELABORADA POR LA S.G.M.}

La promoción del movimiento asociativo familiar no se puede considerar aislado de todo su contexto político. Era un paso más para conseguir una supremacía de la Falange dentro de la dictadura. Hegemonía que se buscó con ahínco hasta 1969, año de la crisis ministerial y el nombramiento de Juan Carlos de Borbón como sucesor de Franco. Momento en el que los falangistas percibieron con claridad que sus postulados habían fracasado totalmente, y sólo quedaba convertir a la Falange en un frente burocrático totalmente servil al Gobierno, tarea que recayó en Fernández Miranda 28.

Una prueba con respecto a que la derrota de los falangistas después del fracaso institucional de Arrese y su posterior dimisión, no había sido total, sino sólo un aplazamiento ${ }^{29}$, lo demuestra una nota escrita en 1959

27 Reglamento del Consejo Nacional de Asociaciones, Orden de 1 de abril de 1959 de SGM, BOM de 10 de abril y publicado en el BOE de 16 de abril de 1959.

28 Cfr. PAYNe, S.G., El Régimen de Franco, op. cit. pág. 586.

29 Cfr. TuselL, Carrero..., op. cit., pág. 246. 
por la SGM acerca de las pautas que se debían seguir en el terreno político en los próximos años ${ }^{30}$. En ésta no se da sensación de derrotismo, sino que, por el contrario, se proponen unas líneas claras de actuación, con el fin de conseguir una presencia preponderante de la Falange en todos los órganos representativos de la España Franquista.

Los objetivos politicos que se propusieron fueron verdaderamente amplios: intentar una mayor representatividad en los sindicatos y conseguir "con las garantías necesarias" el hacer electivos los cargos de Jefes Sindicales, impulsar las actividades del Frente de Juventudes y de la Sección Femenina, intensificar las relaciones con el exterior, impulsar las actividades culturales, crear una escuela de «Formación Política, pero con otro nombre y una finalidad posible», etc. Con respecto a la vida local se propone impulsar todas las asociaciones existentes a escala municipal: «el Movimiento debe procurar ser, en los pueblos y en Provincias, el que lleve a cabo la perfecta relación entre gobernantes y gobernados...". En cuanto a las asociaciones, se propone su impulso y posterior desarrollo, sin perjuicio de «configurar las asociaciones de cabezas de familia tal como se va perfilando después de su primer Congreso". Estas asociaciones, las familiares junto al resto de las dependientes del Movimiento, deberían ser "cauce de expresión muy interesante en materias contingentes y opinables..". Termina la nota en este apartado advirtiendo:

«No debe olvidarse que dentro de un año corresponde realizar de nuevo las elecciones sindicales, municipales, provinciales, etc. y que para entonces, debiera ya funcionar el procedimiento selectivo que las asociaciones representen ${ }^{31}$ w.

En cuanto al sistema representativo, la nota es más extensa recorriendo la representatividad local, provincial y nacional. En el ámbito local y provincial, propone que se inste por conseguir que el Alcalde y el Presidente de la Diputación pudiesen ser electivos, pero sugiere que el proceso sea paulatino:

«no es necesario que, desde el primer momento, estos cargos fueran totalmente electivos. Podría buscarse un procedimiento mixto que permitiera después pasar a una segunda etapa».

30 “Nota de Orientación Política Para el Curso que Empieza», AGA, SGM, caja 227. Consta de cinco folios mecanografiados, sin firma, ni fecha y sin membrete. Debe ser de 1959 por el contexto y porque hace referencia a las elecciones municipales "del año próximo" -que se celebraron en 1960- y también hace referencia al pasado I Congreso de la Familia, que se celebró a

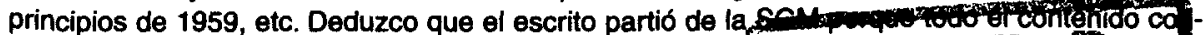
cuerda con lo defendido por ésta.

31 El subrayado es nuestro.

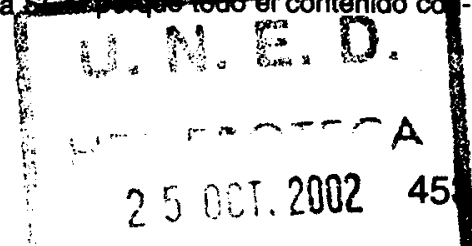


Con respecto a la representación nacional, propone que todos los procuradores elegidos por cada provincia, que eran cuatro como mínimo en cada una de ellas, fueran animados por el Movimiento a que desarrollasen una labor coordinada. Propone convertir al Consejo Nacional en "algo actuante y vivo". Y, al referirse a las Cortes, señala que se debe aprovechar el nuevo Reglamento para "provocar en ellas mayor actividad, absteniéndose el Gobierno de intervenir directamente en muchas ocasiones, para que la propia Cámara vaya logrando soltura y eficacia».

Todo lo expuesto anteriormente era, sin lugar a dudas, muy ambicioso y en muchos casos con un aparente espíritu liberalizador. Espíritu que quedaba ahogado en cuanto la representación debía desfilar necesariamente por el cauce de la Falange.

\section{CREACIÓNY REGULACIÓN DE LAS ASOCIACIONES DE CABEZAS DE FAMILIA}

Las atribuciones concedidas en 1957 a la DNA, se pudieron hacer realidad en el verano de 1963, cuando se dio cauce legal, a través de las Órdenes de SGM, a las Asociaciones de Cabezas de familia y su regulación 32 . El trabajo había sido intenso y aparentemente se desarrollaba bien. A Jorge Jordana de Pozas, nuevo Delegado Nacional de Asociaciones, le escribieron en marzo de 1963 33:

"Querido Jorge: (.) ¡Dios quiera que acertemos! a mi juicio lo importante es poner en marcha un movimiento auténtico de representación a través de los cabezas de familia. (..) no se trata de que se ocupen exclusivamente de asuntos concretos de la familia, como la vivienda, etc. sino de los problemas economicos, sociales y políticos de la Nación. De lo contrario no valdría la pena poner en marcha una organización de esta índole, ni habría, de verdad, democracia orgánica.»

Con la regulación de estas asociaciones por fin se había hecho realidad el deseo de organizar un vastísimo movimiento asociativo en cada población española, ya que se disponia que la DNA podría organizar y promover la creación de una Asociación de Cabezas de Familia

32 Por la Orden de la SGM de 24 de junio de 1963 se creaban las Asociaciones de Cabezas de Familia, su regulación se establecería por la Orden de SGM, BOM, núm. 912, de 1 de julio de 1963, fue publicada en el BOE ese mismo día.

33 Carta enviada a Jorge Jordana de Pozas, desde Madrid el 2 de marzo de 1963. No tiene firma. AGA, SGM, caja 395. 
en cada municipio (art. 1.9), a la que podrían pertenecer todos los empadronados en el mismo, aunque estuvieran afiliados a otras asociaciones (art. 3.9).

Se había conseguido crear un hueco en el rígido esquema asociativo de aquellos años. Ya estaban las asociaciones, a partir de ese momento la lucha se entablaría con el fin de dotarlas de capacidad real para intervenir en la política.

\section{EL PROYECTO DE LEY DE ASOCIACIONES DE CABEZAS DE FAMILIA}

\subsection{El Anteproyecto de la Comisión Permanente de los Congresos de Familia y su paso por el Consejo Nacional}

Las Asociaciones de Cabezas de Familia habían sido reguladas por órdenes salidas de la SGM que, desde el punto de vista "doctrinal y práctico", según el ministerio de la Gobernación, no era un ministerio ${ }^{34}$ y, por 10 tanto, muchas de sus Órdenes no eran publicadas en el BOE ${ }^{35}$. De esta forma, las asociaciones estaban levantadas sobre un cimiento juridico más bien inestable, y podian verse afectadas en cualquier momento por una norma juridica de rango superior 36 .

La SGM conocía el peligro de crear todo el movimiento asociativo familiar a través de órdenes salidas de su propio departamento ministerial, pero no le se le dejó otra opción. El Anteproyecto de Decreto de 1957 que pretendia regularlas, como hemos visto, habia sido rechazado debido a la oposición de Gobernación y de López Rodó, y seguramente ésa era la opinión de Carrero. Los Congresos de Familia fueron un paso más para conseguir sus propósitos, y con ese fin, del Primer Congreso surgió la idea de crear la Comisión Permanente de los Congresos de Familia, que redactaría un Anteproyecto de Ley para regular la participación pública de FHUN.

34 "Nota del Ministro de la Gobernación al 'Primer Borrador del Anteproyecto de la LRF',

35 La Orden de la SGM del 31 de agosto de 1963 -publicada en el BOE el 24 de septiembre de ese año- hace referencia a otra orden anterior y dice, quejándose, «que no hemos visto publicadan.

36 Sin ir más lejos, la Ley que regulaba las Asociaciones -de 24 de diciembre de 1964-, aunque excluía su ámbito de aplicación a las Asociaciones del Movimiento, obligaba a éstas a estar registradas en el Ministerio de Gobernación. 
la familia 37 -en 1957 la SGM redactó un Anteproyecto de Decreto, no de Ley-. Participaron en la elaboración del Anteproyecto de Ley, además de los hombres de la Falange, distinguidas personalidades eclesiásticas, dirigentes de la $A C N$ de P. y de otras asociaciones de la Iglesia ${ }^{38}$. En este Anteproyecto, el artículo $3 .^{\circ}$ declaraba de forma explícita que las asociaciones de la Iglesia podrían promocionar sus propias asociaciones sin depender del orden jurídico del Movimiento.

El borrador del Anteproyecto elaborado por la Comisión Permanente pasó por el Consejo Nacional del Movimiento, donde se introdujeron «ligeras modificaciones», según reconoció la propia SGM ${ }^{39}$. Sin embargo, esas «ligeras modificaciones" no gustaron en absoluto en los ambientes católicos, especialmente entre la Jerarquía Eclesiástica que se opondría frontalmente al Proyecto, al que consideraban muy distinto de aquél elaborado por la Comisión Permanente de los Congresos de Familia. Realmente era asi, ya que entre otras cosas, el citado artículo $3 .^{2}$ que concedía a las asociaciones de la Iglesia autonomía para proponer candidatos había sido suprimido.

\subsection{La oposición de los ministerios al Anteproyecto de Asociaciones de Cabezas de Familia elaborado por la S.G.M.}

La SGM envió al resto de los ministerios tres redacciones distintas del Anteproyecto entre finales de 1963 y principios de 1964 40. Gobernación

37 Así lo reconoce el preámbulo del Proyecto de Ley publicado en el Boletín Oficial de las Cortes (Proyecto de Ley regulando las Asociaciones de Cabezas de Familia, BOCE, 3 de diciembre de 1964).

38 Entre estas personas estaban Mns. Eijó y Garay, Obispo de Madrid; Juan Ricote, obispo auxiliar de Madrid; Mns. Tarancón, arzobispo de Oviedo; Marqués de Vival, Presidente de la Confederación Católica de Padres de Familia; Dr. Hueso, Secretario de la Confederación Católica de Padres de Familia; García Gudal, Secretario para la Familia de la Acción Católica Española; Dr. Victor Fernández, de la Asociación Católica Nacional de Propagandistas. «Nota Sobre la Redacción del Anteproyecto", AGA, SGM, caja 395.

39 «Nota Sobre el Anteproyecto de Ley de Asociaciones de Cabezas de Familia», AGA, SGM, caja 395.

40 El ministerio de la Gobernación asegura que se le envió tres anteproyectos por la SGM. "Nota al Anteproyecto de Ley Regulando las Asociaciones Familiares de Cabezas de Familia" realizado por el Ministerio de la Gobernación, AGA, SGM, caja 395. El único texto que he localizado es el "Anteproyecto de Ley Regulando las Asociaciones de Cabezas de Familia", está en AGA, PG, caja 140. No tiene focha y el papel no tiene membrete, pero éste debe ser uno de los dos últimos referidos por Gobernación, ya que las críticas que se hacen al articulado coinciden con este Anteproyecto. 
observó 41 notables variaciones en los dos últimos anteproyectos con respecto del primero, ya que, según decía, «se acentúa en ellos considerablemente la dependencia de las Asociaciones de Cabezas de Familia respecto de la $S G M »$. Además de esta crítica, el Departamento dirigido por Alonso Vega consideraba que, ante la anterior «arquitectura sencilla y clásica», el Anteproyecto de la SGM pretendia:

"de una parte, mediatizar la representación familiar en el Municipio, del cual es célula básica, interponiendo las nuevas Asociaciones, y, de otra parte, crear un cauce artificioso de representación que desarraigando a las (sic) familia del municipio la insertará "per saltum" en las Diputaciones provinciales, las Cortes y el Consejo del Reino ${ }^{42}$,

No fue únicamente Gobernación el ministerio que se opuso al Anteproyecto de la SGM, sino que otros ministerios también manifestaron sus objeciones. Entre estos se encontraban el de Industria 43, Hacienda 44 y Obras Públicas ${ }^{45}$. Por el contrario, Trabajo, Justicia, Agricultura y Educación no pusieron ninguna objeción ${ }^{46}$. El apoyo de Fraga se preveía seguro, pues, según la nota la SGM, aquél, en la redacción del Anteproyecto, «tuvo importantísima parte cuando era Delegado Nacional de Asociaciones». La posición de López Rodó 47 con respecto al Anteproyecto, tampoco fue muy positiva. El mismo en sus memorias, aunque no se refiere a la posición que adoptó en el momento en que se aprobó en el Consejo de Ministros, la critica por su intento monopolístico; y hace referencia a que el Proyecto suscitó una «natural reacción en varios Ministros". Finalmente, la posición de Carrero debió coincidir con la de los Ministros que se opusieron 48 .

Con algunas ligeras modificaciones, con respecto al último Anteproyecto, el Proyecto de Ley fue aprobado por el Gobierno el 12 de junio de 1964,

41 «Nota al Anteproyecto de Ley Regulando las Asociaciones Familiares de Cabezas de Familia", realizado por el Ministerio de la Gobernación, AGA, SGM, caja 395.

42 El subrayado es nuestro.

43 Carta de López Bravo a Solís con fecha dos de abril de 1964. AGA, SGM, caja 395.

44 "Nota Para el Ministro Secretario General del Movimiento Sobre el Anteproyecto de Ley de Asociaciones de Cabezas de Familia», AGA, SGM, caja 395.

45 Informe en AGA, SGM, caja 395.

46 "Nota Para el Ministro Secretario General del Movimiento Sobre el Anteproyecto de Ley de Asociaciones de Cabezas de Familia", AGA, SGM, caja 395.

47 LÓPEZ Rodó, L., Memorias, op. cit., pág. 490.

48 No he encontrado referencias directas al respecto, y tampoco debió encontrar nada Tusell cuando estudió el archivo personal de Carrero, ya que lanza esa hipótesis basándose en las memorias de López Rodó. Cfr. TuseLL, J., Carrero, op. cit., pág. 287. Hipótesis bastante fundamentada, debido a la animadversión de Carrero a la Falange. 
pero no entraría en las Cortes hasta diciembre de ese mismo año. Para entender su importancia, nos pueden servir unas declaraciones de Silva 49 , uno de los hombres más implicados en todo el proceso de la Ley: "se veía próxima la incorporación de un tercio de procuradores 'familiaristas' y la SGM tomaba posiciones para controlar o influir en este 'tercio'».

\subsection{La supuesta oposición de las H.O.A.C.}

Además de las observaciones críticas de la mayoría de los Ministerios, el ataque más fuerte al Anteproyecto tuvo su origen en un escrito atribuido a las HOAC 50 , posteriormente enviado a todos los obispos españoles y publicado en el diario francés Le Monde. El documento es incisivo y va al fondo de las cuestiones sin ningún tipo de edulcoramientos. Consta de dos partes; la primera analiza el articulado; la segunda es una reflexión acerca de los fines políticos del Proyecto. Estos últimos eran, según el informe: evitar que el asociacionismo se deslizara lentamente hacia la formación de partidos políticos, impedir a las asociaciones dependientes de la Jerarquia Eclesiástica española la posibilidad de participar en el nombramiento de candidatos para los organismos representativos y, por último, favorecer el proselitismo político del Movimiento a través del sector familiar.

En cuanto al primero y al segundo de los objetivos, respondía el documento, que el «terror pánico" que se tenía a los partidos políticos era innecesario, debido a que el uaparato policiaco informativo y represivo es más que suficiente para impedirlo"; sin embargo se le reconoce que tenía la ventaja de evitar que los «católicos" pudiesen formar sus propias asociaciones:

«el proyecto tiene la ventaja de impedir que grupos católicos independientes puedan constituir estas Asociaciones Familiares Libres, con las que darian una eficacia real, mediante su representación pública, a la doctrina sobre la sociedad familiar. $Y$ es contra esa posibilidad contra la que parece expresamente dirigida la Ley, pese a sus protestas de respeto a la Iglesian.

La crítica iba directamente al fondo del verdadero objetivo de todo el Proyecto, y, por otra parte, manifiesta ei motivo por el que las asociaciones católicas se opusieron al mismo.

49 Silva Muñoz, Federico, Memorias..., op. cit., pág. 91.

50 Esta crítica está incluida en el dossier enviado a Solís sobre el Anteproyecto. En ella se afirma que fue publicada en el diario francés, que fue enviada a numerosos prelados españoles y que su autoría "se supone" tiene origen en las HOAC. AGA, SGM, caja 395. 
En cuanto al tercer fin político -proselitismo político del Movimiento en el sector familiar-, según el informe, era fácil conseguirlo debido a que los movimientos familiares católicos no habían formado la conciencia de los derechos civiles de la población. Pone como ejemplo de lo anterior, el que muchas asociaciones católicas enviaran telegramas de agradecimiento tras la publicación del Proyecto de Ley. Por último, el informe entiende que al Movimiento le sería fácil hacer ese proselitismo debido al «confusionismo político-religioso que los agentes del Movimiento crean en la propaganda para la constitución de las Asociaciones Familiares del Movimiento". Como es conocido este confusionismo fue ampliamente difundido desde las altas instancias de poder a través de multitud de medios.

\subsection{El Proyecto remitido a las Cortes por el Gobierno}

El Proyecto de Ley 51 disponía que el Movimiento Nacional sería el que promoviese la organización de las Asociaciones de Cabezas de Familia (art. 3). Con respecto a la capacidad operativa de las asociaciones de cabezas de familia, éstas tendrían la posibilidad de participar en la representación pública para distintos organismos locales, provinciales y nacionales. Las Asociaciones de Cabezas de Familia, en instituciones locales: benéficas, educativas, de sanidad, etc. ${ }^{52}$. La Federación Provincial de Asociaciones Familiares podría estar representada en las Diputaciones. Finalmente, la Federación Nacional, en las Cortes, en el Consejo del Reino y en el Consejo Nacional. Además, deberían estar representadas en una multitud de organismos a todos los niveles (arts. 36 a 38), como eran, entre otros, el Consejo Nacional de Economía, Consejo Nacional de Educación, Consejo de Distritos Universitarios, Consejo Técnico de Universidades Laborales, Consejos de Vivienda, de Sanidad, de Protección de Menores etc.

Según el articulado, la mayoría de las críticas de los distintos ministerios al Anteproyecto de la SGM tenían razón y seguían vigentes, con escasas modificaciones, en el Proyecto de Ley. Las pretensiones de los falangistas inevitablemente chocaban con las respectivas competencias de los distintos ministerios sobre una vasta gama de actividades de todo tipo: educación, economía, obras públicas, etc. Estaba claro que se inten-

51 El Proyecto fue aprobado por el Gobierno el 12 de junio de 1964, y publicado en el BOCE el 3 de diciembre de ese año.

52 Al haberse retirado del Proyecto el que las asociaciones familiares pudiesen presentar candidatos a concejales, su representación se daría en otras instituciones locales -educativas, de caridad, sanitarias, etc.-. 
taba crear un Estado dentro de otro Estado. La duplicidad de funciones entre el Estado y la Falange fueron una constante durante todo el periodo del franquismo; y si Carrero, como hemos visto, criticaba esa duplicidad a principios de los años cuarenta, la situación no varió significativamente con el tiempo y, como reconoció el propio Solís a López Rodó, la misma situación se podía observar en 1962:

«Hay que terminar - decía Solís-con la dualidad Estado Movimiento. El Movimiento es hoy un apéndice del Estado. Esto es malo (..) El Movimiento ha de utilizar el cauce representativo del Municipio y del Sindicato, sin crear organismos burocráticos en colisión con los Estatales."

Pero, como reconoce López Rodó, estas ideas no eran las de Solís, sino las suyas propias, y si el Ministro Secretario las había pronunciado era con la intención de complacer al que sería ministro de Planificación, ya que la crisis ministerial era inminente y Solís creía que López Rodó tendría un papel imiportante en ella 53 .

Las Asociaciones de Fines Específicos -dependientes de Gobernación- y las de la Iglesia Católica no dependerían de este nuevo régimen juridico; pero, si querían participar en la vida pública, lo tendrían que hacer a través de los cauces previstos en esa Ley. (art. 1 y art. 4). Es decir, se debían someter a la SGM, por lo que su capacidad real de promocionar políticos a distintos niveles era prácticamente imposible.

\subsection{La oposición de la Jerarquía al Proyecto de Ley}

La oposición más efectiva sin lugar a dudas -según los testimonios que iremos viendo de la propia SGM-procedió de parte de la Jerarquía Eclesiástica. El 7 de julio de 1964, poco menos de un mes después de haberse aprobado el Proyecto por el Gobierno, la Conferencia de Metropolitanos Españoles envió una «nota verbal» a Solís ${ }^{54}$, en la que se expresaba extrañeza por el articulado del Proyecto de ley:

"...nos sentimos obligados a expresar nuestra sorpresa y sentimiento porque el texto del citado proyecto de ley apenas ha tomado en consideración los resultados del trabajo y la redacción aportada al proyecto de ley por la Comisión oficialmente nombrada para el estudio del mismo y de la que formaron parte algún Prelado y representantes de algunas asociaciones familiares constituidas y dirigidas por la Iglesia».

53 Cfr. LOPEZ Rodó, Memorias, op. cit., págs. 302-303.

54 AGA, SGM, caja 395, está firmada por Casimiro Morcillo. 
La crítica de ésta iba fundamentalmente contra la redacción de los artículos $3 .^{9}$ y $4 .^{9}$ del Proyecto de Ley, en los que, se obligaba a todas las asociaciones que quisieran participar en la presentación de candidatos debían aceptar la tutela del Movimiento. Estos decian:

Art. $3 .^{\circ}$ El Movimiento Nacional promoverá la organización de Asociaciones de Cabezas de Familia, que tendrán por función principal servir de cauce a la participación de aquéllas en las tareas públicas en lo que hace relación a sus fines e intereses.

Art. 4. ${ }^{\circ}(\ldots$.$) [las asociaciones] tendrán los derechos y deberes del régimen$ asociativo del Movimiento.

Esta oposición de la Jerarquía obligó al Delegado Nacional de Asociaciones a entablar negociaciones con el fin de llegar a un acuerdo. Solis 55 , el 8 de octubre de 1964, envió una carta a Don Casimiro Morcillo, por aquel entonces Arzobispo de Madrid-Alcalá, explicándole cómo se estaban desarrollando las negociaciones, y proponiéndole un texto alternativo para paliar en algo lo que significaban esos artículos $3 .^{\circ}$ y $4 .^{\circ}$ del Proyecto de Ley. En esta carta, Solís manifestaba al arzobispo que estaba satisfecho con las negociaciones que se estaban llevando a cabo entre el Delegado Nacional de Asociaciones, Jorge Jordana de Pozas, y el obispo Juan Ricote. Entre los acuerdos a que se habían llegado se encontraba la inclusión de un nuevo artículo entre el tercero y el cuarto. Este artículo pretendia salvaguardar los intereses de la Iglesia en lo que se refería al asociacionismo y su participación política. El nuevo texto decía:

«La Iglesia Católica podrá mantener, organizar y promover la constitución de Asociaciones de Cabezas de Familia, en relación con sus propios fines y que tendrán el estatuto y los derechos y deberes correspondientes, con arreglo al derecho concordado y su desarrollo legal y reglamentario. Nada de lo establecido en la presente Ley podrá ser aplicado o interpretado para restringir los citados derechos o agravar los deberes correspondientes.

La participación activa de las Asociaciones de Cabezas de Familia de la Iglesia en los cauces representativos públicos, se realiza por los medios establecidos en la presente Ley. Su utilización es voluntaria para las citadas Asociaciones de Cabezas de Familia de la Iglesia en las Federaciones Provinciales y Unión Nacional, se produce de pleno derecho, tan pronto como se acredite su condición".

Esta redacción era, según la carta de Solís, «idéntica a la que contenía el Anteproyecto redactado hace algunos años, por la Comisión Per-

55 En AGA, SGM, caja 395. Consta de dos folios mecanografiados. 
manente de los Congresos de Familia", y como es fácil percibir, era sustancialmente distinta a la del Proyecto de Ley. Por lo que es evidente que las «ligeras modificaciones" incorporadas al Anteproyecto primitivo, según afirmaba un documento interno de la $S G M{ }^{56}$, no eran tan pequeñas, sino que eran cualitativamente significativas.

Gracias a las conversaciones referidas por Solís, se producía una aproximación entre la Jerarquía Católica y la SGM. El acercamiento no era gratuito, ya que los hombres del Movimiento sabían que una oposición tajante de la Jerarquía podía hacer fracasar el Proyecto de Ley, como así sucedió finalmente. Independientemente del resultado final, esta primera aproximación dio resultado momentáneamente, ya que el arzobispo de Madrid-Alcalá, Casimiro Morcillo, figura de gran prestigio entre la Jerarquía, agradeció las atenciones de Ministro Secretario, y en carta de uno de noviembre de 1964 le respondía 57:

"Con la mayor atención he leído el artículo que me propone y se refiere a las Asociaciones de la Iglesia. Se lo he dado a leer a otros Prelados y a todos nos ha parecido que responde adecuadamente a los deseos de la Jerarquía tal como habian sido expresados en las conversaciones habidas anteriormente a la presentación del proyecto ley a las Cortes."

Sin embargo, no parece que todos los Prelados estuvieran de acuerdo con las apreciaciones de Monseñor Morcillo, sino que la oposición por parte de algunos arzobispos fue intensa y constante. Lideró el enfrentamiento Marcelino Olaechea ${ }^{58}$, entonces arzobispo de Valencia, que no se mostró satisfecho con la modificación introducida. Ante esto hay que hacer notar que, a pesar de las mejoras, las asociaciones de la Iglesia para promocionar políticos afines a escala provincial y nacional, deberían ingresar en las Federaciones Provinciales y en la Unión Nacional de Asociaciones Familiares (UNAF), controladas por la SGM, por lo que estarían supeditadas a ésta. Y esa fue la interpretación del arzobispo de Valencia, quien se propuso paralizar el Proyecto y con ese motivo mantuvo una intensa actividad epistolar con la SGM. De esta forma, Marcelino Olaechea ${ }^{59}$, en carta de 1

56 “Nota Sobre la Tramitación del Anteproyecto", AGA, SGM, caja 395.

57 Carta de Casimiro Morcillo a Solis, 1 de noviembre de 1964. La carta está fechada en Roma debido a los trabajos del Concilio Vaticano II.

58 La aceptación de los cambios propuestos, no debió ser muy compartida por la jerarquía porque, como se verá más adelante, los metropolitanos en pleno y el propio Juan Ricote, obispo auxiliar de Madrid, uno de los mejores expertos en cuestiones familiares, la rechazaron en enero de 1965.

59 Carta de Marcelino Olaechea a Jorge Jordana de Pozas el 1 de diciembre d 1964. AGA, SGM, caja 395. 
de diciembre de 1964 a Jorge Jordana de Pozas, aunque aceptaba que las asociaciones de la Iglesia asumieran los principios del Movimiento, rechazaba la tutela de este, y le expresaba su opinión acerca del asociacionismo entendiendo que las asociaciones que quisieran participar en la representación pública no tenían que estar «encuadradas en el sistema jurídico del Movimiento". Dos dias después de enviada esta carta se publicaría en el Boletín de las Cortes el Proyecto de Ley, pero las discusiones continuaron. Marcelino Olaechea ${ }^{60}$, el 23 de diciembre de 1964, respondía a una carta de Jordana de Pozas del 11 de diciembre. En ella, el Prelado, con cierta ironía, se mostraba muy comprensivo con el Delegado Nacional de Asociaciones con respecto a que éste creyera que era «inevitable" que "el Movimiento tuviera de ser el cauce a través del cual las preocupaciones y aspiraciones de la Sociedad lleguen al Estado». Pero el Arzobispo no estaba de acuerdo con esa «inevitabilidad", y haciendo un juego de palabras, le señalaba a Jordana de Pozas:

«Me parece a mi inevitable 61 el deber que incumbe al Movimiento de velar para que esas preocupaciones y aspiraciones se ajusten siempre a los principios fundamentales del régimen español; pero el cauce ha de ser, en nuestro caso, las entidades estatales: Gobiernos civiles, Ministerio de la Gobernación, Consejo de Ministros...».

$Y$ terminaba dejando clara su posición: lo que le preocupa no es la redacción de la Ley en cuanto a la función que las asociaciones iban a poder tener, si no su vinculación a la SGM:

«El articulado de la Ley de regulación de Cabezas de Familia me parece bueno de veras, pero la vinculación de los Cabezas de Familia al Sistema Juridico Asociativo del Movimiento, no contribuirá, créame que no contribuirá, a la mayor unión de los que son y quieren ser buenos españoles»

El 18 de enero de 1965, volvió el Prelado a escribir a Jordana de Pozas, donde da cuenta de las conversaciones que el arzobispo de Valencia había tenido con Solís y con Herrero Tejedor ${ }^{62}$. Lo más significativo en ella era la crítica de monopolio hacía la SGM:

"Yo no dudo de que se va dando al Movimiento por ellos [Solís y Herrero Tejedor], por Vd. y por otros que le rodean, una apertura necesaria, y que tal vez no consentía antes la dureza de los tiempos que hemos vivido.

60 Carta de Marcelino Olaechea a Jorge Jordana de Pozas el 23 de diciembre de 1964. AGA, SGM, caja 395.

61 Subrayado del original.

62 AGA, SGM, caja 395. Está escrita en papel con membrete del Arzobispo de Valencia. 
A pesar de todos los empeños, no creo que Vds duden de que no pocos españoles les siguen teniendo, sin pararse bien a mirar, como a duros herederos de una absorvencia política.»

\subsection{Las enmiendas al Proyecto de Ley y el informe de la Ponencia}

El 19 de diciembre de 1964, Solís escribió al Presidente de las Cortes 63 animándole a que los trabajos de la Ponencia se desarrollaran con normalidad con el fin de que «todo quede ultimado a tiempo de que el Proyecto pueda someterse al primer Pleno que se celebrem. Del Presidente de las Cortes dependia en gran medida que un Proyecto prosperase o no. Y si bien, éste nunca actuaría en contra del Gobierno, sí que podría influir en el ánimo de éste a la hora de impulsar o paralizar el Proyecto en cuestión, por lo que no es extraño que Solís instara al Presidente de las Cortes a la diligencia.

La Ponencia de la Comisión Especial, formada ex profeso para la Ley, estuvo formada por Jordana de Pozas, José Moreno Torres, Luis Rodríguez de Miguel y por Federico Silva. Es decir, tres personas directamente relacionadas con los falangistas y que habian participado en todos los trabajos que se habían realizado para promocionar las asociaciones familiares del Movimiento, contra una -Silva- que era la voz de los defensores de las asociaciones católicas. Los miembros de la Ponencia tuvieron que hacer frente al Proyecto remitido por el Gobierno y a 31 enmiendas, entre las que había tres a la totalidad, hechas por Marcelino Olaechea, Lucas María de Oriol Urquijo y Manuel Aranegui Coll.

La SGM intentó fiscalizar las enmiendas, como lo demuestra una "nota interior", donde se recomendaba a la DNA que "coordinara" las posibles enmiendas que se pudieran hacer 64 . Es posible que este tipo de circulares fuera habitual para el caso de proyectos de leyes que interesaban de forma especial a la SGM, ya que se remitió una circular parecida en el caso de la LRF 65.

La nota de la DNA tuvo su efecto, pues de las treinta y una enmiendas presentadas ${ }^{66}$, sólo siete intentaban arninorar el monopolio de la Falan-

63 AGA, SGM, caja 395.

o4 "Nota Interior" del Vicesecretario General de Movimiento (Herrero Tejedor) al Secretario General Técnico. AGA, SGM, caja 395. 2754.

65 Se puede ver la nota enviada por la SGM a los gobernadores civiles en AGA, Interior. caja

66 Las enmiendas al Proyecto de Ley "Asociaciones de Cabezas de Familia", se pueden ver en Archivo de Cortes, Serie General, caja 2372. 
ge con respecto al asociacionismo; el resto, a excepción de dos o tres que se limitan a hacer alguna precisión, estaban en la línea de lo que la SGM había estado defendiendo, e incluso, algunas solicitaban modificaciones encaminadas a reforzar el monopolio falangista.

Entre las enmiendas de los falangistas destaca la de Miguel Fagoaga, proponía en su enmienda incluir un artículo que asegurara la independencia de las asociaciones de la Iglesia. La redacción del artículo es exactamente igual a la que Solis había accedido a incluir en el Proyecto de Ley. Lo anterior nos muestra, con casi toda seguridad, que el enmendante había recibido el «encargo" de parte de la SGM. Miguel Fagoaga, debía ser un hombre de total confianza de SGM, pues fue propuesto, a principios de 1966, para pertenecer a la directiva de la UNAF. De esta forma, que un falangista hiciera una enmienda favoreciendo a la Iglesia, podría ayudar a disminuir la tensión entre ambas instituciones.

La importancia del Proyecto de Ley quedó reafirmada por la calidad de los miembros de la Comisión Especial creada ad hoc. Entre sus 47 componentes se encontraban personajes tan significativos como Pío Cabanillas, Juan José Espinosa, Torcuato Fernández Miranda, Licinio de la Fuente, Jorge Jordana de Pozas, Laureano López Rodó, Alberto Martín Artajo, Fernando Martín-Sánchez Juliá, Casimiro Morcillo, Marcelino Olaechea, Justo Pérez de Urbel, Federico Silva, etc. 67

\subsection{Sigue la oposición de la Jerarquía}

Aunque el informe de la Ponencia al Proyecto de Ley tiene fecha de 12 de febrero de 1965 , el texto definitivo redactado por ésta se debía conocer mucho antes, ya que, en una reunión de algunos obispos tenida en la mañana del 29 de enero de 1965, se decidió enviar una carta a Franco solicitando la retirada del Proyecto de Ley 68 . En esa reunión participaron Marcelino Olaechea y el resto de metropolitanos, los obispos Guerra Campos y Juan Ricote, más Monseñor Torella y Federico Silva -que era el único seglar de la reunión-. La carta colectiva se envió a través del Presidente de las Cortes. Silva la redactó esa misma tarde, donde se exponía que los metropolitanos tenían «una profunda preocupación [por] el alcan1964.

67 La composición de la Comisión Especial se puede ver en el BOCE de 3 de diciembre de

68 Me baso para el siguiente párrato en Silva Muñoz, Federico, Memorias..., op. cit. págs. 91 93. 
ce del Proyecto de Ley de Asociaciones de Cabezas de Familia (...) pues no cree que se acomode a los principios de derecho natural que amparan la constitución de la familia como célula social básica» y por ello pedía se reconsiderara antes de aprobarla en las Cortes.

Esa misma noche, Silva 69 le entregó la carta a Esteban Bilbao, Presidente de las Cortes en aquél momento, quien la recibió con «viva complacencia». A las pocas horas, estaba en manos de Franco. Silva termina su relación de lo sucedido aquella tarde diciendo: “Del malhadado Proyecto nunca se volvió a hablar.»

Es de notar que en esa reunión estaba Monseñor Ricote, y quedan pocas dudas de la presencia de Casimiro Morcillo entre los metropolitanos citados de forma genérica por Silva. Parece ser que la opinión de éstos había cambiado, o por lo menos que habían cedido ante la oposición de algunos obispos, pues como vimos, tanto Monseñor Ricote como Casimiro Morcillo habian llegado a un acuerdo con Solis acerca de la redacción del artículo tercero. Es muy posible que fuera Marcelino Olaechea el que les había convencido de lo poco acertado que era el nuevo artículo introducido por la ponencia.

La pugna epistolar del metropolitano valenciano continuó después del 30 de enero, y se han podido localizar documentos de SGM muy posteriores a esta fecha instando a seguir con el proceso de tramitación del Proyecto de Ley. De lo que debemos deducir, que las palabras de Silva acerca de que nunca más se volvió a hablar del asunto, no son del todo exactas. Así, el mismo 30 de enero, Marcelino Olaechea envió a Herrero Tejedor, en aquel momento Vicesecretario General del Movimiento, una carta 70 en ese sentido. En ésta, Monseñor Olaechea, consideraba que la mejor opción era retirar el Proyecto por el momento, y si eso no era posible, volvía a insistir en que lo mejor era que las asociaciones familiares dependieran de las de Gobernación y solicitaba que, no sólo que las asociaciones de la Iglesia tuvieran total libertad para presentar candidatos a los distintos niveles, sino que también lo pudieran hacer «si así lo desean, las otras Asociaciones de Cabezas de Familia y sus Federaciones, legalmente instituidas en orden de la Representación Pública Familiar»

Como se puede ver, la pretensión del arzobispo era de gran alcance, y de haberse aprobado su proposición hubiera podido significar una apertura en la representación en las Cortes. Por lo anterior, no es de extrañar

69 Silva Muñoz, Federico, Memorias..., op. cit., págs. 91-93.

70 AGA, SGM, caja 395. 
que esta petición no tuviera buena acogida, no sólo por la SGM, sino también por el Gobierno en su conjunto.

El 8 de febrero, Marcelino Olaechea volvia a insistir, en carta a Herrero Tejedor ${ }^{71}$. En ella, al hablar de la redacción del Proyecto de Ley entiende que si la Iglesia acepta el Proyecto de Ley con la inclusión del artículo $3 .{ }^{\circ}$ puede salir muy perjudicada cara a la opinión pública ya que la Iglesia reconoce para ella unos derechos que otros no pueden conseguir:

"Quién no ve que todo eso puede llevar a no pocos, con disgusto de la Iglesia, a creer que el Proyecto de Ley reconoce a las Asociaciones de Cabezas de Familia de la misma, un trato de particular favor, que no reconoce a las otras? (sic)

No, no; esas palabras son del todo inútiles, engendran confusión y no favorecen a la Iglesia.

Ella quiere para sus Asociaciones de Cabezas de Familia lo que quiere, y con igual fuerza, para todas las otras que sean legalmente reconocidas".

Y añadía, que de no cambiarse el Proyecto, él se opondría totalmente. En esta carta de Monseñor Olaechea, se puede ver la crítica de una de las situaciones más comunes durante el franquismo: la utilización tanto de los símbolos, como de las declaraciones de la Iglesia, en favor de una determinada política. Esa misma situación era criticada por el documento atribuido a las HOAC, analizado anteriormente. Éste al referirse al preámbulo del Proyecto de Ley, en el que se dice que el mismo «respeta expresamente los derechos de la Iglesia", señala que:

"Se declara 72 que respeta expresamente los derechos de la lglesia a través de los cauces asociativos, etc. (preámbulo de la Ley)

Se usa habitualmente el artificio de negar los derechos naturales, sociales y políticos de la población, pero hace alardes de reconocer los de la Iglesia, maniobra que tiene dos efectos:

1. La Iglesia da la impresión de que, viendo reconocidos sus derechos eclesiásticos, ignora en silencio la violación de los derechos de los demás.

2. La Iglesia, en el ejercicio de los derechos suyos, tiene que subordinarse a los cauces jurídicos asociativos que le sean señalados por el Partido"

Realmente era fácil para el Régimen apoyarse en la Iglesia. Desde la Carta Colectiva de 1937, donde la casi totalidad de los obispos españoles

71 AGA, SGM, caja 395.

72 Subrayado del original. 
defendieron el Alzamiento Nacional, el apoyo de la Iglesia al Régimen aparecia, popularmente, como inquebrantable. Es cierto que no fue del todo asi, especialmente en lo que se refiere a las relaciones de la Iglesia española con la FET de las JONS, pues la mentalidad totalitaria de muchos de los hombres de esta última, debía chocar necesariamente con el deseo de autonomía de la Iglesia respecto a la enseñanza, apostolado obrero, asociacionismo etc.

A pesar de que el Proyecto de ley estaba sentenciado, la SGM y la Jerarquía Eclesiástica continuaron las conversaciones, como mínimo, durante un año más ${ }^{73}$.

\section{LAS FEDERACIONES PROVINCIALES Y LA UNIÓN NACIONAL DE ASOCIACIONES FAMILIARES (UNAF)}

La SGM, a la altura de 1965, había fracasado en su deseo de utilizar a las asociaciones como cauce de representación en los distintos órganos políticos de la vida nacional. No por eso cejó en su empeño, ni perdió el tiempo, sino que, a la vez que se seguía trabajando para que la LACF reanudara su tramitación, la DNA iba articulando el movimiento asociativo a fin de que fuera éste el que presentara los candidatos por el nuevo cauce -ya vislumbrado desde hacía varios años- de los Procuradores en Cortes del Tercio Familiar 74 . Durante el mismo año de 1965, se fueron creando las Federaciones Provinciales de Asociaciones de Cabezas de Familia. En diciembre -a pesar de que su regulación no se hizo hasta abril de $1966^{75}$ - ya estaban constituidas más de 15 de estas Federaciones, y se esperaba que para el segundo trimestre de 1966 estarían constituidas todas las Federaciones en cada una de las provincias 76 .

73 En el verano de 1965 se celebró en San Sebastián un curso sobre Problemas Familiares donde se debatió ampliamente de nuevo la necesidad de aprobar ei Proyecto paralizado (Informe remitido por Jordana de Pozas el 2 de septiembre de 1967, «Informe sobre el IV Curso de Problemas Familiares", AGA, SGM, caja 395). Posteriormente, en febrero de 1966 se reunieron 18 Presidentes de las Federaciones de Asociaciones Familiares donde se volvió a discutir el tema ( «Informe de la I reunión Nacionai de Presidentes de Federaciones Provinciales de Asociaciones Familiares", AGA, SGM, caja 395). Las conclusiones de esa reunión se envió a los obispos (Carta de Jordana de Pozas a Solís, fechada el 21 de febrero de 1966. AGA, SGM, caja 395).

74 Cfr. Silva muñoz, Federico, Memorias Políticas, op. cit., pág. 91.

75 Fueron creadas por la Orden de SGM de 18 de abril de 1966.

76 Carta de Jorge Jordana de Pozas a Solís, 27 de diciembre de 1967. AGA, SGM, caja 395. 
Las Federaciones Provinciales se regian prácticamente por las mismas normas que se previeron para ellas en el fallido Proyecto de la LACF, estudiado anteriormente. Sin embargo -por las razones vistas-, no incluían en su regulación la posibilidad de presentar candidatos a las corporaciones locales, provinciales o a las Cortes, que a la postre, era uno de los principales fines para las que fueron constituidas. Tanto es asi que David Ferrer Garrido 77 en su enmienda a la posterior Ley de Representación Familiar en Cortes, quejándose de que el Proyecto de Ley aprobado por el Gobierno no incluía la posibilidad de que las asociaciones familiares pudiesen presentar candidatos, consideraba que si no se cambiaba el Proyecto de Ley, toda la labor del Movimiento pareceria que toda la labor realizada por el Movimiento (..) habría sido estéril y no contabilizada, en el momento de perfilar cauces de representación familiar en los altos Organismos del Estado."

En mayo de 1966 se aprobaron los estatutos de la UNAF 78. En ella estarian incluidas todas las Federaciones Provinciales de Asociaciones Familiares (dependientes del Movimiento) y las Federaciones de las Asociaciones Familiares de ámbito nacional (Iglesia y otras) ${ }^{79}$.

De esta forma, en menos de 3 años, desde la orden de 24 de junio de 1963 (por la que se empezaron a crear la Asociaciones de Cabezas de Familia) hasta mayo de 1966 (cuando se creó la UNAF) se había llegado a un movimiento asociativo perfectamente estructurado; con un organigrama claro y muy jerarquizado, y con una base legal con suficiente solidez como para poder subsistir a pesar de los envites de Gobernación y Presidencia. Pero toda esa complicada trama de cuadros y organismos de nada serviria si no se conseguía lo que se había buscado desde el principio: que las asociaciones tuvieran el monopolio de presentación de candidatos. El Proyecto de la LACF, dormido en las estanterías de las

77 Enmienda núm. 86 a la LRF. ACE, Serie General, caja 1179-2.

78 Orden de la SGM de 30 de mayo de 1966.

79 La Comisión que se encargó de organizar la primera reunión de la UNAF, prevista para julio de 1966, estaba compuesta, entre otros, por: Jorge Jordana de Pozas (Presidente); Manuel Guijarro, Torcuato Fernández Miranda y Adolfo Garachana Múñoz (vocales); Luis Conde Muner (Secretario). Para ocupar su presidencia se presentó una candidatura, en cuyas listas estaban, además de Jorge Jordana, Marcelo Fernández Nieto (Presidente de la Asociación Provincial de Familias Numerosas de Salamanca), José Maria González (Presidente de la Asociación de Niños Subnormales) y Luis Conde Muner (Secretario General de la Comisión Permanente de los Congresos de Familia). Entre los miembros de la UNAF que deberían votar la candidatura estaban, entre otros muchos, Pedro Doblado Claveríe, Miguel Fagoaga, Torcuato Fernández Miranda, Adolfo Garrachana Muñoz, que fueron algunos de los más activos en las discusiones en torno a la LRF, defendiendo posiciones cercanas a la SGM. 
Cortes, era de difícil solución, por lo que era perentorio buscar otra salida sino se quería quedarse en una vía muerta y con un ingente trabajo sin resultados positivos.

La oportunidad, largamente esperada, se produjo una vez aprobada la LOE, el 14 de diciembre de 1966, que preveía la inclusión de un tercio de los procuradores por elección directa a través de la Familia. Éste fue el nuevo aviso de salida para reanudar la lucha, con el fin de conseguir lo que durante tantos años se les había negado.

\section{LAS ASOCIACIONES DE CABEZAS DE FAMILIA EN LA L.R.F.}

No cabe duda de que, desde el punto de vista político, la clave de todo el Proyecto de Ley de Representación Familiar en Cortes, fue la participación, o no, de las asociaciones en las elecciones, y así lo reconocía Gobernación: «El problema político-central es el de si se admiten o no las Asociaciones para la propuesta de candidatos" 80 .

El tema era de gran importancia y de no fácil solución. Las discusiones que surgieron durante el Proyecto de la LACF, latentes por un tiempo, despertaron de su letargo y cobraron nuevos impulsos ${ }^{81}$. Hubo de nuevo diferencias de criterio entre los distintos ministerios: la SGM 82 en sus anteproyectos propuso que las asociaciones familiares dependientes de su ministerio, y solamente ellas, pudiesen presentar candidatos; Gobernación 83 y Presidencia ${ }^{84}$ se opusieron. Finalmente, el Proyecto de Ley no contempló esa posibilidad. Se presentaron 33 enmiendas proponiendo este nuevo cauce de presentación de candidaturas; la Ponencia, que rechazó las enmiendas, presentó un voto particular a favor de ellas; los de-

80 «Nota del Ministro de la Gobernación al 'Primer Borrador del Anteproyecto de la LRF'», FHUN.

81 Jesús López Medel en su enmienda al Proyecto de Ley de la LRF señalaba que: a(e)stá en el ánimo de todos el anterior Proyecto de Ley de representación pública de la familia que fue elevado al Gobierno a través de la SGM, y que no llegó a discutirse en la Comisión especial designada al efecto.» Enmienda núm. 12 a la LRF, ACE, Serie General, legajo 1179-2.

82 «Anteproyecto de la LRF", enero de 1967, AGA, SGM, caja 92 y «Primer Borrador del Anteproyecto de la LRF «, AGA, SGM, caja 92. Este es de febrero de 1967. Nótese que aunque se define como primer borrador, hay otro anterior con fecha de enero, el motivo debió ser que aquél no se envió a los ministerios y sólo se utilizó internamente en la SGM.

83 "Nota del Ministro de la Gobernación al "Primer Borrador del Anteproyecto de la LRF'", FHUN.

84 “Nota de Presidencia al Informe de la Ponencia sobre la LRF», AGA, SGM, caja 630. 
bates fueron acalorados y la prensa le dedicó numerosos titulares y comentarios políticos a favor o en contra.

Los más interesados en que las asociaciones pudieran presentar candidatos fueron de nuevo los falangistas y los "católicos", aunque ambos diferían con respecto a qué tipo de asociaciones podrían presentar candidatos. Las Asociaciones Familiares habian tenido hasta ese momento, desde el punto de vista político, poca importancia, debido a que todos los intentos realizados, y vistos anteriormente, habían fracasado. Pero los cuadros de mando ya estaban organizados, o con posibilidad de hacerlo en poco tiempo, por lo que, una vez aceptado el movimiento asociativo como cauce de presentación de candidatos, bastaba con promocionar a sus políticos a través del organigrama de esas asociaciones. En 1967, los únicos que tenian esta posibilidad eran el Movimiento y los «católicos». El Movimiento, gracias a sus asociaciones dependientes de la Delegación Nacional Asociaciones; los católicos, apoyados en su vasta red de asociaciones de apostolado seglar estrechamente ligadas a la jerarquía.

Entre los que se opusieron a las asociaciones estaban los tecnócratas de Presidencia, Gobernación, los monárquicos -a través de $A B C$ - y los que deseaban una apertura mayor que la estrecha de las asociaciones. Los tecnócratas se opusieron fundamentalmente porque carecían de asociaciones afines y porque, de hecho, no las necesitaban; su ascenso al poder era por vía de su prestigio profesional y de los contactos personales con Carrero. Los monárquicos, además de tener poca implantación en la población y escasa posibilidad de ensamblar un movimiento asociativo, dependían de Presidencia para lograr el regreso de la Monarquía. Y tanto es así que los argumentos que utilizó el diario monárquico fueron literalmente los mismos de Presidencia en documentos internos para oponerse a las asociaciones: lo que nos sugiere que, o esos textos internos fueron facilitados a $A B C$, o que los editoriales fueron escritos por alguien muy relacionado con Presidencia 85 . Por último, se opusieron aquellos que eran críticos con el Régimen y temían a unas asociaciones que, tal y como pedían sus defensores, especialmente la Falange, sólo llevarían al privilegio de unos grupos muy concretos.

Por parte de los defensores de las Asociaciones, la SGM movilizó toda su organización intentando que sus asociaciones pudiesen tener relevancia política. De las 33 enmiendas presentadas de un total de 103, solicitando la inclusión del nuevo cauce, la mayoría procedían de hombres

85 Es conocido que muchos de los editoriales del $A B C$ en esos años eran escritos por Florentino Pérez Embid. 
relacionados directamente con el Movimiento, siendo, muchos de ellos, cargos relevantes dentro de la DNA ${ }^{86}$.

Los argumentos utilizados desde las altas instancias de la SGM ${ }^{87}$ en favor del cauce asociativo fueron, de forma sucinta, el elevado número de cabezas de familia que participaban en ellas, lo que les hacia, según ellos, muy representativas; la inmensa labor desplegada por el movimiento asociativo en pro de una mayor participación de los organismos familiares en la vida pública; la necesidad de unas organizaciones que actuasen de promotores de los candidatos para cualquier proceso electoral, o de lo contrario, se volvería a la masiva abstención de la elección para los concejales del Tercio Familiar, etc. Los argumentos anteriores esgrimidos por SGM en los anteproyectos fueron repetidos una y otra vez en las enmiendas -algunos de ellos literalmente- y en la Comisión: parecía un contrasentido, según esas enmiendas, que los diputados provinciales, sin ningún tipo de relación con las familias, pudieran presentar candidatos -como proponía el Proyecto de Ley-y las asociaciones no 88; que éstas eran las más cualificadas para presentar candidatos ${ }^{89}$; que la participación asociativa en el juego político no era más que un reflejo fiel de las Leyes fundamentales del Movimiento y de la LOE 90; que por su elevado número y su labor en favor de la familia se las debía tener en cuenta ${ }^{91}$; etc.

Los "católicos" defendieron a las Asociaciones especialmente a través del diario Ya y en las discusiones en el seno de la Comisión. Sin em-

86 Entre las personas, relacionadas con la SGM, que presentaron enmiendas o participaron activamente en la Comisión en defensa de las Asociaciones, estaban: Jorge Jordana de Pozas, Delegado Nacional de Asociaciones y Presidente de la UNAF.; Pedro Doblado Claveríe, Vocal de la Federación de Asociaciones Familiares de Tenerife; Miguel Fagoaga, miembro de la Comisión Permanente de los Congresos de la Familia Española; Torcuato Fernández Miranda, Consejero Nacional y miembro de la Comisión Permanente de los Congresos de la Familia Española; UIpiano Jambrina, Presidente de la Federación Provincial de Asociaciones Familiares y Consejero Nacional; Adolfo Garachana, Consejero Nacional. Los cargos de los anteriores se pueden ver en AGA, SGM, caja 395.

87 "Nota de SGM a las Observaciones del Ministro de la Gobernación al 'Primer Borrador de la LRF'". AGA, SGM, caja 92.

88 Augusto de BÁRCENA Y Reus. Enmienda núm. 5 a la LRF; José María Gutierrez Castillo, enmienda núm. 56, ACE, Serie General, legajo 1179-2.

89 José Manuel Mateu de Ros, Enmienda núm. 15 a la LRF; Amadeo Almajano Garces, enmienda núm. 83.

90 Miguel FagoagA, enmienda núm. 41; Ramón Bonilla Echeverría, enmienda núm. 44; José María Mendoza GuineA, enmienda núm. 54; Ignacio GarCla LOPEZ, enmienda núm. 55; David FERRER GARRIDO, enmienda núm. 86.

91 Antonio lacleta Pablo, enmienda núm. 80, Miguei IaUhzun Goicoa, enmienda núm. 87. 
bargo el número de enmiendas presentadas por este sector fue muy escaso. En la Comisión estuvieron especialmente activos Navarro Rubio y Monseñor Olaechea. El primero 92 consideró que era «ineludible la necesidad de montar en este específico terreno unas organizaciones vivas y poderosas que sirvan de contrapunto a las de los intereses particulares o sociales»; y el segundo ${ }^{93}$ solicitó que el Gobierno remitiera a las Cortes un nuevo Proyecto de la LACF. Por su parte, Ya (opositor en muchos otros terrenos al Movimiento-Organización) se alió con los hombres de la Falange y se hacía eco de sendas conferencias de Jorge Jordana de Pozas, a las que el diario católico dedicó amplios titulares: «Las asociaciones familiares deben promover candidatos" y "No se ha contado con las asociaciones familiares» 94 .

Gobernación 95 entendía que no era procedente que las asociaciones familiares pudieran proponer candidatos, sin embargo, en su informe conservó las formas de la cortesía y la diplomacia, no siendo del todo tajante:

«...ya que -decía Gobernación- ni se deben estimular las Asociaciones, ni se les debe dar la espalda a las mismas, pues sería tanto como ponerse una venda en los ojos..."

Por lo que concluía: «más vale no aventurarse legislativamente por el camino de las Asociaciones, sin perjuicio de que políticamente no debamos desconocer su existencia». Es decir, sí, pero no, en un lenguaje muy típico del franquismo, donde se reconocía en documentos internos la necesidad de no dar la espalda a la realidad política, a la vez que no se daban los pasos necesarios para adaptarse a esa misma realidad.

Como es bien conocido, la alergia que Presidencia tenía a todo lo que estuviera teñido de «azul» era grande. Por eso, no es de extrañar que su oposición fuera la más tajante y, por razones de peso político, la más decisiva. Presidencia 96 consideró que «lo que se pretende canalizar en el Proyecto de Ley es la representación de las familias (..) y no, en absoluto, la representación de unas asociaciones», pues éstas «representarían,

92 Recogido en Madrid, 25 de mayo de 1967. Como es conocido, el Diario de Sesiones no se empezó a publicar hasta 1970. Las discusiones se pueden ver en cuartillas mecanografiadas en ACE, Serie General, legajo 4908.

93 Madrid, 25 de mayo de 1967.

94 Los titulares corresponden a los días 12 y 21 de marzo de 1967, respectivamente. FHUN.

95 "Nota del Ministro de la Gobernación al 'Primer Borrador del Anteproyecto de la LRF'",

96 «Nota de Presidencia al Informe de la Ponencia sobre la LRF", AGA, SGM, caja 630. 
más que a las familias, a dichas asociaciones". Y continuando, después de indicar que el cauce asociativo iba contra las Leyes Fundamentales, concluyó que existían muchas razones para evitarlas:

“... existen razones juridicas formales (..) y razones politicas de fondo ${ }^{97}$ y forma que deben impedir de manera absoluta el establecimiento y la aceptación de que las Asociaciones familiares puedan presentar candidatos para las elecciones familiares en las Provincias".

La oposición de los monárquicos a las asociaciones se vertió en forma de editorial en $A B C{ }^{98}$, que consideraba que si se permitía este cauce:

«es evidente que representarían, más que a todas las familias, a las Asociaciones mismas, que sería las que lanzasen sus candidaturas y a las cuales los elegidos quedarían hipotecados";

El editorial concluía con parecidos términos a los utilizados por Presidencia:

«Existen -creemos- razones jurídicas formales, y razones políticas de fondo que deben impedir de manera absoluta el que la Asociaciones familiares vengan a convertirse en pieza perturbadora de la representación."

Las líneas que hemos subrayado del texto de Presidencia y del editorial del $A B C$, demuestran que existía una estrecha relación entre ellos en este tema en concreto.

Pasando de las visiones generales, que tenía cada una de las partes, a las cuestiones más concretas, podriamos resumir en tres puntos fundamentales las diferencias entre unos y otros con respecto a la conveniencia o no de dotar a las asociaciones familiares de capacidad política: su constitucionalidad, la posibilidad de que las asociaciones se convirtieran en partidos políticos y qué tipo de asoriaciones podrían presentar candidatos.

\subsection{Las asociaciones como cauce de representación y las Leyes Fundamentales}

El sistema político imperante en la España franquista era, según la definían los partidarios del Régimen, la «democracia orgánica», por lo que toda representación política debía respetar, por lo menos en teoría, esa

97 El subrayado es nuestro.

98 ABC, 23 de mayo de 1967. El subrayado es nuestro. 
premisa. Hasta el momento de la entrada de los procuradores familiares en Cortes no había habido grandes problemas desde el punto de vista teórico: la capacidad de los cabezas de familia de elegir un tercio de los concejales para los ayuntamientos no dejaba de ser una cuestión menor. A partir de la LRF, ya no se trataba de legislar la representación en los ayuntamientos, sino en la Cámara Legislativa, donde -quizá en un futuro no muy lejano- se podría hacer una verdadera labor fiscalizadora al Gobierno. En un sistema en donde el equilibrio político era esencial, era importante tener controladas las Cortes para así poder inclinar la balanza en un sentido o en otro. Por eso, la inmediata entrada a las Cortes de un número relativamente importante de caras nuevas puso en tensión a los guardianes del Régimen: era preciso asegurar por todos los medios que los candidatos fueran adictos al mismo, y evitar que las otras familias del Régimen, distintas a la propia, pudiesen copar los escaños en litigio. Esta situación hizo afinar a los teóricos acerca de la «organicidad» o «inorganicidad» del sistema elegido. Si en muchos otros aspectos estuvieron enfrentados, en una cosa todos coincidieron: los que proponian otros cauces a los propios estaban defendiendo posturas contrarias a las Leyes Fundamentales.

De nuevo, las «familias" que disponían de unas asociaciones consolidadas y de unos cuadros de dirigentes bien formados -Movimiento y asociaciones confesionales- defendieron con denuedo que el cauce del asociacionismo era, posiblemente, el único que respetaba el sistema orgánico del Régimen español. Por el contrario, aquéllos que no tenían medios asociativos, en el momento de la elaboración de la ley, ni posibilidad de tenerlos en un futuro inmediato, calificaron al cauce de las asociaciones como contrario a la democracia orgánica, y por lo tanto a las Leyes Fundamentales recogidas en la LOE.

La SGM, en el preámbulo de su Anteproyecto de Ley ${ }^{99}$, señalaba que su Proyecto era concorde con los Principios Fundamentales del Movimiento, pues respetaba, según ella, escrupulosamente el principio orgánico ya que rechazaba democracia liberal a la vez que ratificaba con el Anteproyecto que "sólo son sujetos de representación las unidades sociales y las instituciones". De esta forma el Ministro Secretario del Movimiento 100 afirmaba que si el Régimen era una democracia orgánica donde los representantes del pueblo no llegaban gracias al voto indivi-

99 "Anteproyecto de LRF", AGA, SGM, caja 92.

100 «Observaciones del Ministro Secretario del Movimiento al Anteproyecto de Ley de Representación Familiar en Cortes", de 9 de febrero de 1967, AGA, SGM, caja 92. 
dual, sino a través de las sociedades intermedias, la exclusión de las Asociaciones Familiares transformarían «la representación familiar de un sistema orgánico, en una elección censitaria, con evidente contradicción con el espiritu y la letra de la Ley Orgánica del Estado", y afirmaba que al obviar a las asociaciones se garantizaba...

"...un sistema oligárquico ${ }^{101}$ y olvida que la representación de la sociedad en el Estado ha de operar por conducto de órganos sociales intermedios, como son las Asociaciones Familiares y sus Federaciones provinciales».

Solís se quejaba también de que, si por una parte, se le negaba la presentación de candidatos a las asociaciones, por otra, se le otorga este privilegio a otras corporaciones, como son las diputaciones, dándose de esta forma una confusión «de los distintos cauces de la representación orgánica».

Las críticas siguieron de manos de los prohombres del Movimiento. Jordana 102, como Delegado Nacional de Asociaciones, fue el más activo y, en su contestación al Ministro de Gobernación, no dudaba en considerar «extraordinariamente grave» la exclusión de las elecciones a un movimiento asociativo que engloba más de un millón ochocientos mil cabezas de familia. Además, en sendas conferencias - una vez ingresado el Proyecto de Ley en las Cortes-, Jordana 103 sería más directo en sus críticas al Proyecto de Ley al que consideraba: infiel a la democracia orgánica, contrario a la doctrina pontificia y defensor de una verdadera oligarquía. Por todo eso, si el Proyecto no se rectificaba, lo que venía a significar que se "secuestra la opinión social», amenazaba con que "las asociaciones familiares le retirarán su apoyo y la combatirán con todos los medios a su alcance". Los medios para oponerse al Proyecto de Ley, en un sistema en donde el poder estaba muy concentrado, no eran muchos y se limitarian a la prensa del Movimiento - $y$ en este caso con el apoyo de la católica- y a las enmiendas en las Cortes.

De las 33 enmiendas presentadas en las Cortes en favor del nuevo apartado e), que preveía a las asociaciones como cauce de representa-

101 Subrayado del original.

102 «Nota de SGM a las Observaciones del Ministro de la Gobernación al 'Primer Borrador de la LRF' . AGA, SGM, caja 92. En su portada está escrito a mano «Jordana"; es muy probable que fuese él quién redactase ese escrito. Fue Jordana quién, como Delegado Nacional de Asociaciones, llevó casi todo el peso de la creación de las Asociaciones Familiares, sus Federaciones Provinciales y finalmente de su Unión Nacional, de la que él era el Presidente.

$103 \mathrm{Ya}, 12$ y 23 de marzo de 1967. Las conferencias se impartieron en Pamplona y Burgos respectivamente. 
ción, nueve consideraban que si se prescindía de las asociaciones el sistema se convertiría en un sistema de elección inorgánico y por lo tanto iría contra los Principios Fundamentales del Movimiento y de la Ley Orgánica del Estado ${ }^{104}$. Con parecidas formas argumentaba en la Comisión Monseñor Olaechea 105 -apoyado por numerosos procuradores- al considerar indispensable una ley de Asociaciones Familiares «para que los futuros candidatos ostenten una representación orgánica». Navarro Rubio ${ }^{106}$, hablaría con parecidos términos: «no hay razón para que ésta [la familia] no cuente en su representatividad con análogos caminos a los que ya tienen señalizados el Municipio y el Sindicato". Este fue apoyado por Allende, Fernández Miranda, Sevilla Andrés, Villegas Girón y Mateu de Ros, entre otros.

Presidencia 107 no podía estar de acuerdo con esta interpretación de la democracia orgánica y entendía que " «debido a que las Asociaciones no constituyen entidades territoriales, ni profesionales (...) los criterios que determinan su actuación tienen que ser necesariamente ideológicos [por lo que] se pasaría de una representación orgánica de intereses, a una representación ideológica de voluntad".

De la misma opinión que Presidencia era $A B C{ }^{108}$, que afirmaba que la presentación de los candidatos por parte de las asociaciones "daría entrada en el sistema de representación español a un nuevo cauce susceptible de politización ideológica, que rompería con el criterio orgánico que preside el sistema español».

\subsection{Las Asociaciones que podrían presentar candidatos}

Los partidarios del asociacionismo católico se habían aliado momentáneamente con los hombres del Movimiento en varios puntos: para defender la inclusión del nuevo apartado, para alejar los temores de que estas serían la avanzadilla de los partidos políticos y para calificar de in-

104 Las enmiendas que consideraban lo referido (ACE, Serie General, Legajo 1179-2) eran las de Pio Cabanillas (enmienda núm. 92), Rafael Salgado Torres (enmienda núm. 77), José Moreno Torres (enmienda núm. 70), Jesús lópez Medel (enmienda núm. 12), Ignacio García López (enmienda núm. 55), Adolfo Garrachana MuÑoz (enmienda núm. 63), Ramón Bonilla Echevaraia (enmienda núm. 44), Antonio Garcia Bernalt (enmienda núm. 55) y Pedro Doblado Claverie (enmienda núm. 47).

105 Ya 24 de mayo de 1967.

106 Madrid, 24 de mayo de 1967.

107 «Nota de Presidencia al Infome de la Ponencia sobre la LRF», AGA, SGM, caja 630.

$108 A B C, 23$ de mayo de 1967. 
constitucional a la LRF si se las excluía. Pero, en el momento de proponer qué asociaciones serian las que podrian presentar candidatos, sus criterios fueron divergentes y prácticamente excluyentes.

El Anteproyecto y el Primer Borrador ${ }^{109}$, ambos salidos de SGM con la finalidad de dar impresión de pluralismo habian incluído la posibilidad de que las Asociaciones Familiares Provinciales -es decir las que no dependían del Movimiento- pudiesen presentar candidatos. Pero ésas asociaciones, para poder ejercer esa capacidad, tenían unas condiciones especiales. En primer lugar, deberian estar incluidas en las Federaciones Provinciales de Asociaciones Familiares, lo que traducido viene a significar estar controladas por la DNA. Además, éstas deberían tener más de 500 afiliados, cuestión nada fácil en provincias pequeñas. $Y$, finalmente, deberian estar legalmente constituidas con un año de antelación a la fecha de la convocatoria de las elecciones. Este último punto, como hizo notar el Ministerio de la Gobernación 110, les impedía de hecho el poder participar en las primeras elecciones que se celebrasen. Es decir, sólo y únicamente las asociaciones del Movimiento serían las que -según estos primeros anteproyectos-podrían presentar candidaturas. Arriba 111 lo decía más claramente:

«El asociacionismo familiar, como cualquier otro, hay, para decirlo gráficamente, que «engancharlo» a alguien, y el sitio de enganche no es más que uno: aquél a quien corresponda legalmente promover la vida política (..) a este sitio lo llama Movimiento Nacional la Ley Fundamental Orgánica del Estado».

A pesar de esas declaraciones del órgano de prensa del Movimiento, la SGM tuvo que desistir en sus pretensiones, debido a la oposición de Gobernación y Presidencia. La SGM 112 en una redacción posterior propuso mitigar en parte las condiciones para esas federaciones familiares no dependientes de la DNA, en donde se les seguía exigiendo la necesidad de tener un año de vida antes de las elecciones, pero se les posibilitaba la participación, sin tener que estas sometidas a la jurisdicción de la DNA. Se permitía de esta forma que las asociaciones de la Iglesia -prácticamente las únicas que eran independientes del Movimiento- pudiesen elegir a sus propios candidatos.

109 «Anteproyecto de LRF», y «Primer Borrador del Anteproyecto de la LRF", ambos en AGA, caja 92.

110 "Nota del Ministro de la Gobemación al 'Primer Borrador del Anteproyecto de la LRF", FHUN.

111 Arriba, Editorial, 26 de mayo de 1967.

112 «Nota de SGM a las Observaciones del Ministro de la Gobernación al 'Primer Borrador de la LRF'". AGA, SGM, caja 92. 
De las enmiendas presentadas a favor del nuevo cauce, la mitad de los enmendantes 113 fueron exclusivistas a favor de las Federaciones del Movimiento; once solicitaron que pudieran presentar candidatos todo tipo de asociaciones familiares ${ }^{114}$ y por el contrario, sólo dos 115 fueron los que solicitaron que las asociaciones del Movimiento no tuvieran esa facultad. Como se ve la actividad enmendante de los falangistas fue mucho más activa que la de los hombres procedentes del sector católico.

En los debates en la Comisión, Monseñor Olaechea 116 apoyaba a los falangistas en la petición de las asociaciones pero discrepaba en qué tipo de asociaciones debían participar y decía en los debates en la Comisión: "¿asociaciones? Las indispensables. ¿Autenticidad representativa? si. Pero asociaciones vivas, representativas." $Y$ atacaba a las Asociaciones del Movimiento considerando que si se admitían entonces las Cortes serían:

«un diálogo entre el Estado y sus delegados nombrados por el que tiene el poder político", pues estas organizaciones, en palabras del prelado, "son asociaciones mediatizadas sin carácter político representativo. Son mediatizadoras porque tienen en la mano el poder político, además del poder económico."

Los falangistas contestaron al Prelado a través de Raimundo Fernández Cuesta 117 , quien estuvo de acuerdo con la defensa de las asociacio-

113 Solicitaban que la presentación se hiciera únicamente a través de la Junta de Gobierno de la Federación Provincial de Asociaciones Familiares Luis Arroyo ArroYo (enmienda núm. 4), Augusto de Báacena y Reus (enmienda núm. 5), José Manuel Mateu de Ros (enmienda núm. 15), Antonio lacleta Pablo (enmienda núm. 80), Rafael fernandez de Vega (enmienda núm. 82), José Morán Navadón (enmienda 90), Vicente Leama AndReu (enmienda núm. 26), José María Gutierrez del Castillo (enmienda núm. 56), Adolfo Garrachana Muñoz (enmienda núm. 63), Amador Almazano Garcés (enmienda núm. 83), Juan de LlOBEt llavari (enmienda núm. 85), Miguel IRURzUn GoICOA (enmienda núm. 87), Ramón Muñoz-Gonzalez (enmienda núm. 88), Ezequiel Puig MaEstro-Amado (enmienda núm. 91).

114 José Lafont Ouveras (enmienda núm. 10), José López MEdel (enmienda núm. 12), Ulpiano Jambrina Bonafonte (enmienda núm. 34), Pedro Doblado Claverie (enmienda 47), Antonio Gafcia Bernalt (enmienda núm. 51), Miguel fagoaga (enmienda núm. 41), Ramón Bonilla Echeverria (enmienda núm. 44), José Moreno Toraes (enmienda núm. 60), Rafael Salgado TorRes (enmienda 77), David Ferrer Garaido (enmienda 86), Pío Cabanillas (enmienda núm. 92)

115 Estos fueron luis SánChez Agesta (enmienda núm. 79) y Eduardo Villegas Giaón (enmienda núm. 57).

116 Debates en la Comisión, Ya, 25 de mayo de 1965.

117 Debates en la Comisión, Arriba, 25 de mayo de 1967. Fernández Cuesta afirmaba: «para evitar una proliferación excesiva de candidaturas, deben basarse en la presentación por parte de las Federaciones Provinciales, donde están representadas no sóto las asociaciones creadas por la Delegación Nacional del mismo nombre, sino también las reguladas por el Ministerio de la Gobernación". 
nes, pero con ciertas limitaciones: las de pertenecer a las Federaciones Provinciales. Jorge Jordana de Pozas 118 apoyaba a su correligionario y fue más explícito:

"a no ser que mi obispo declare expresamente lo contrario, este procurador, el más humilde de los católicos españoles, votará en contra de que se incluya en el nuevo apartado a la Confederación Católica de Padres de Familia».

Como es conocido la Confederación Católica de Padres de Familia fue promovida por la Jerarquía y deseaba que pudiese presentar candidatos.

En la Comisión algunos partidarios de las Asociaciones, viendo la cerrada postura de SGM se opusieron a las mismas para evitar males mayores. Así, el rector de Salamanca, doctor Balcells, quien pidió "asociaciones vivas, expresivas de las corrientes de opinión pública» 119, votó en contra del apartado que las incluía entre los cauces para presentarse a candidato. $A B C{ }^{120}$, que ya se había manifestado en contra de la participación asociacionista en las elecciones, aumentó su oposición debido a las restricciones con las que se las queria introducir en el Proyecto de Ley, y consideraba que de ser aceptado el cauce asociativo para la presentación de candidatos...

“...se politizaría en exclusividad, a favor de dos grandes, dignísimimas, no exclusivas, pero sí excluyentes fuerzas políticas. Las que monopolizan, por un lado, el Movimiento; las que monopolizan por otro, las organizaciones seglares de la lglesia en España".

El Alcázar 121, aunque sí estuvo de acuerdo con la participación de las asociaciones en el juego político, no lo estaba tanto con el tipo de asociaciones que podrían hacerlo:

«Lo que hay que evitar a toda costa es la sanción de privilegios(..) Igual nos da que se trate de asociaciones ligadas a la SGM, que de las Asociaciones que llevan el nombre de católicas. Ni las primeras pueden representar al Movimiento-comunión en los principios, ni las segundas pueden representar a los católicos».

118 El Alcázar, 29 de mayo de 1967.

119 El Alcázar, 26 de mayo de 1967.

120 ABC, 24 de mayo de 1967.

121 El A/cázar, 29 de mayo de 1967. afirmaba: «[la unidad en los principios fundamentales] ya no es obstáculo para pedir el reconocimiento jurídico del pluralismo político y social que manifiesta la vida española en el actual momento histórico. No se ve ya como incompatible la unidad de España con la sanción del pluralismo ideológico o, al menos, asociativon. Asimismo, reconoce que es necesario legislar el pluralismo político ya que, «si no se hace ahora, habrá que hacerlo pronto, reformando nuestra Ley vigente de Asociaciones". 
Finalmente, la Ponencia tras examinar las enmiendas consideró, sin dar razón alguna, que prefería mantener el texto enviado por el Gobierno, sin perjuicio de que alguno de los ponentes emitiera un voto particular cuando llegara el caso. En la Comisión el texto se aprobó con nueve votos en contra y con el voto particular del ponente Asís Garrote en favor de las asociaciones familiares.

Una vez más, los deseos de los defensores de las asociaciones familiares habian fracasado. La representación se abriría gracias a los procuradores familiares, pero la falta de apoyo de un grupo organizado impidió que se pudiera hablar de una campaña suficientemente eficaz que llegase a la mayoría de los electores.

\subsection{Las Asociaciones y los partidos políticos}

En este caso, los defensores de las asociaciones como cauce de representación también se aliaron para intentar alejar el temido "fantasma» de los partidos políticos. Monseñor Olaechea y Navarro Rubio 122 consideraron que, teniendo en cuenta las medidas tomadas por el Régimen, no era probable que surgieran los partidos si se permitía que las asociaciones participaran en las elecciones; en todo caso, el peligro -argüía Navarro Rubio- era el contrario: el asociacionismo venía a solucionar, según él, «una posible anemia y vacío político». Por su parte, Monseñor Olaechea defendía que, «la importancia de la familia como núcleo político es un hecho real y difícilmente podemos presentar el fantasma de los partidos políticos, dada la estructura actual de las leyes fundamentales».

Los falangistas apoyaron las tesis de los católicos, y fueron más allá que éstos en su argumentación: las asociaciones no sólo no eran un peligro para la democracia orgánica, sino que, de no darles poder político, los partidos políticos aparecerían. Fernández Miranda ${ }^{123}$ argumentaba que, de no aprobarse ese cauce de presentación de candidatos, se provocaría un vacío político que aprovecharían los enemigos del Régimen para cubrirlo con partidos y organizaciones atomizadas. De la misma opinión era

122 Madrid, 24 de mayo de 1967.

123 Crónica de los debates en la Comisión, Madrid, 23 de mayo de 1967. Esta opinión no era nueva, sino que, como mínimo, procedía de los finales cincuenta. Así, en un documento se decía: «...debe añadirse que, al lado de la representación sindical, las Asociaciones de Cabezas de Familia son el único tapón serio al intento de resucitar viejas, o crear nuevas, agrupaciones políticas de tipo partidista (...)". uInformación confidencial sobre el Proyecto de Decreto de Asociaciones de Cabezas de Familian, fue elaborado por SGM. AGA, SGM, caja 60. 
Jorge Jordana de Pozas, quien alegaba que, por no permitir un movimiento asociativo vivo, se acabaría «estableciendo un régimen individualista y atomizado que haría ineficaces las futuras Cortes» 124 . Y esa era la creencia de la SGM 125 en la respuesta que hizo a las observaciones de Gobernación a sus Anteproyectos.

El Departamento dirigido por Don Camilo 126 rechazó las asociaciones basándose, entre otras cosas, en los numerosos obstáculos que la SGM pretendía poner a las asociaciones no dependientes de ella a la hora de proponer candidatos. Presidencia ${ }^{127}$ compartia el temor a los partidos politicos y consideraba que si se permitía el cauce asociativo, "antes o después conduciria la transformación de dichas asociaciones en el germen de futuros partidos políticos". La misma argumentación -con casi idénticas palabras- utilizó $A B C$, en un editorial del día 23 de mayo. Por su parte, el carlista Arellano, en la Comisión, puso el dedo en la llaga:

"Existe el peligro de que las asociaciones familiares puedan tener carácter de partido y entonces cabe esta disyuntiva: o se admiten todas las Asociaciones, lo que sería peligroso, o una sola -la encuadrada en el Movimiento- y entonces podrá hablarse de un monopolio inaceptable.» 128.

$Y$ ahi estaba el problema: si se permitía una verdadera representatividad -siempre dentro de los límites impuestos por el Régimen-era necesario que las asociaciones presentaran candidatos de forma libre. Pero esta opción, para muchos, sería el germen de unos partidos políticos que pronto pedirían más participación en el poder. De esta forma El Alcázar ${ }^{129}$, en un titular afirmaba: «La difícil cuestión es conseguir asociaciones familiares vivas, evitando que se transformen en partidos políticos 0 monopolio." Ante esto no podemos olvidar que la oposición más constante dentro del Régimen se realizó en estos últimos años a través de las asociaciones legalmente constituidas de apostolado seglar, muy especialmente de las HOAC.

Por pocas posibilidades que hubiera con respecto a la aparición de partidos políticos, el Gobierno no estaba en absoluto dispuesto a correr

124 Conferancia pronunciada en Pamplona, Ya, 12 de marzo de 1967.

125 «Nota de SGM a las Observaciones del Ministro de la Gobernación al 'Primer Borrador de la LRF'". AGA, SGM, caja 92.

126 «Nota de SGM a las Observaciones del Ministro de la Gobernación al 'Primer Borrador de la LRF'". AG'A, SGM, caja 92.

127 "Nota de Presidencia al Informe de la Ponencia sobre la LRF», AGA, SGM, caja 630.

128 Debates en la Comisión, 24 de mayo, citado en El Alcázar, 24 de mayo de 1967.

129 El Alcázar, 24 de mayo de 1967. 
riesgos en este terreno. La SGM lo sabía y quería jugar la baza de las Asociaciones, conociendo que, de aprobarse, sólo lo serían las controladas por la DNA, que era la única que tenía medios para salvaguardar la pureza ideológica. Pero, en este caso se produciría un monopolio con el que gran parte del Gobierno, y muy especialmente Presidencia, no estaban de acuerdo. La solución más fácil fue la de prescindir de ellas.

\section{LA IMPORTANCIA REAL DE LAS ASOCIACIONES DE CABEZAS DE FAMILIA, SUS FEDERACIONES Y LA U.N.A.F.}

El interés despertado por el tema del asociacionismo familiar fue evidente $y$, a veces, apasionado. Pero, ¿realmente, las asociaciones familiares tenían importancia en la vida del país, o eran más bien, unas entidades ficticias al servicio de unos intereses concretos y sin una verdadera actividad? Para la SGM no había duda de que las Asociaciones de Cabezas de Familia -con sus órganos provinciales y nacional- tenían una gran importancia. Entre otras muchas razones, por la gran cantidad de afiliados que tenian 130: en febrero de 1966 existían 530 Asociaciones de Cabezas de Familia 131, 32 asociaciones de familias numerosas ${ }^{132}$, y 41 asociaciones de Padres de Niños Subnormales.

En julio de 1966, cuando se creó la UNAF, ésta agrupaba a 1143 Asociaciones Familiares, con unos cuatro millones de adheridos ${ }^{133}$. Finalmente, en 1967, la UNAF declara tener un millón ochocientos mil cabezas de familia afiliados, pertenecientes a 1.700 Asociaciones de Cabezas de Familia ${ }^{134}$. Es decir -contando a cinco miembros por familia-, 9 millones de españoles estaban representados en esas asociaciones. Una cifra nada despreciable.

130 El elevado número de sus asociaciones y de sus miembros fue uno de los argumentos utilizados en las enmiendas para solicitar que estas asociaciones pudiesen presentar candidatos. Así lo hicieron, por ejemplo, Juan Llovet Llavari (enmienda núm. 85), Miguel IRURzUN (enmiend núm. 87), José MORENO TORRES (enmienda núm. 60) etc.

131 Carta de Jorge Jordana de Pozas a Casimiro Morcillo, 16 de febrero de 1966. AGA, SGM, legajo 395.

132 Anexo 4. , de la reunion de presidentes de Federaciones Provinciales de Asociaciones provinciales de Asociaciones Familiares. febrero de 1966. AGA, SGM, caja 395.

133 El dato está en el Archivo Francisco Franco, leg. 35, fol. 7 a 12. Tomado de la nota a pie de pagina en SuÁrez Fernandez, Luís, Francisco Franco y su tiempo, tomo VII, Fundación Nacional Francisco Franco, Madrid, 1984, pág. 350.

134 «Observaciones del Ministro Secretario General del Movimiento al Anteproyecto de LRF», AGA, SGM, caja 92. 
Presidencia 135 , en el documento elaborado para defender los fundamentos en los que descansa la LRF, destaca el valor de la familia, entre otras cosas, por su gran actividad asociativa y, citando los informes de la UNAF, dice que las «Asociaciones Familiares agrupan a 1.800 .000 cabezas de familia». Sin embargo, en un documento escrito pocos meses después reconoce que "sólo un porcentaje muy reducido de cabezas de familia forma parte de las Asociaciones familiares" 136.

Se puede decir que los datos de la UNAF eran posiblemente ciertos, pero sólo en cierta manera. Por los datos mencionados podemos ver que, de febrero a julio de 1966, han pasado de 530 a 1.143 Asociaciones de Cabezas de Familia; y a principios de 1967 estaban constituidas ya 1.700. Es evidente que la constitución se hacía por "decreto" del Gobernador Civil, y sólo los trámites legales retardaban un poco la creación de estas Asociaciones. La actividad de estas asociaciones, surgidas desde arriba, no debió ser muy fructífera en general. En 1973, la Dirección General de Seguridad elaboró un informe acerca de las actividades de estas Asociaciones en toda España. Los resultados hablan por sí mismos: por ejemplo, de las de Almería se dice que fueron constituidas por el Gobernador Civil y que "la mayoría de ellas no ha desplegado actividad alguna", de las de Jaén se afirma que «su actividad es prácticamente nula». En Isla Cristina, prácticamente pertenecían a la Asociación todos los cabezas de familia ${ }^{137}$, etc.

Una vez constituidas las asociaciones en el ámbito local era fácil constituir la Federación Provincial de Asociaciones de Familia: las de Cabezas de Familia lo tenían que hacer obligatoriamente y, las de fines específicos -en su mayor parte, promovidas por el Movimiento ${ }^{138}$ - no tuvieron inconveniente en afiliarse. Las únicas que estuvieron más reticentes a la hora de afiliarse a las Federaciones Provinciales fueron las dependientes de la Jerarquía eclesiástica, y así lo manifestaba Jordana de Pozas en carta a Solís ${ }^{139}$ :

"para tu satisfacción te diré que hasta ahora no hemos encontrado ninguna resistencia significativa para federarse por parte de todas las asociaciones, que, por ser de fines específicos, no estaban sujetas a nuestra jurisdicción. Solamente por parte de algunas asociaciones confesionales se nos ha solicitado un dilación en la respuesta. supongo que motivadas por la ausencia de las jerarquias eclesiásticas producida por el Ccncilion.

135 "Fundamentos Teóricos del Proyecto de la LRF", AGA, SGM, caja 630.

136 "Nota de Presidencia al informe de la Ponencia sobre la LRF", AGA, SGM, caja 630.

137 AGA, Cultura, caja 431.

138 "Nota de SGM a las Observaciones del Ministro de la Gobernación al 'Primer Borrador de la LRF'". AGA, SGM, caja 92.

139 La carta es del 27 de diciembre de 1967. AGA, SGM, caja 395. 
De esta forma son compatibles las versiones de la UNAF y de Presidencia: era cierto que un gran porcentaje de los Cabezas de Familia pertenecía a las esas asociaciones, pero no es difícil suponer que, los alcaldes ${ }^{140}$, a petición del Gobernador Civil, constituyeran las asociaciones y pidieran a los habitantes del pueblo que se inscribieran, o quizá, se les inscribia directamente, para después tener una vida, en la mayoría de los casos, inexistente.

Todo el Movimiento asociativo se empezó a desarrollar en previsión de la incorporación de los Procuradores familiares, pues al fin y al cabo, la participación de las familias en las tareas públicas era su «función principal» 141. Por eso, la SGM constituyó en poquísimo tiempo un vasto movimiento asociativo. Movimiento asociativo que fue ficticio: una vez que la legalidad impidió la participación de estas asociaciones en los distintos niveles de la vida pública, se olvidaron prácticamente de los otros fines para las que fueron creadas: cooperar con las instituciones educativas, de beneficencia y de emigración, colaborar con las cuestiones de moralidad pública etc. ${ }^{142}$. De lo anterior se puede deducir que, aunque unas pocas asociaciones sí desplegaron cierta actividad, la mayoría fueron constituidas con el solo objeto de servir de cauce a los hombres del Movimiento en su promoción política.

\section{EL ESTATUTO DE LAS ASOCIACIONES POLITICAS $Y$ LAS ASOCIACIONES FAMILIARES}

El Estatuto de la Asociaciones Políticas, aprobado en diciembre de 1974, que tantas expectativas había despertado y que tan pocos frutos dio, aparentemente se sale fuera de nuestro tema de las asociaciones de cabezas de familia en su intento por promover candidatos a los cargos públicos. Silva ${ }^{143}$, aunque consideró que ese intento fue de gran trascendencia, entendía que no se podía equiparar con el estatuto de asociaciones:

140 No era infrecuente que la Asociación tuviera su domicilio en la Delegación Provincial, caso de Alicante, o en los ayuntamientos. (Lista de las asociaciones y sus domicilios en AGA, SGM, caja 395).

141 Borrador de carácter reservado acerca de la regulación de la UNAF. AGA, SGM, caja 395.

142 Dictamen del Consejo Nacional sobre la "Representación Pública de la Familia», de marzo de 1963. AGA, SGM, caja 395.

143 Silva Muñoz, Federico, Memorias Politicas, op. cit., pág. 91. 
uun intento asociativo de gran trascendencia, pero ceñido al movimiento "familiarista", que no se puede confundir con los proyectos de convertir la estructura del Movimiento Nacional en una pluralidad de asociaciones políticas que solamente afloró en los últimos tiempos de Franco, y ante la perspectiva de cambio"

A pesar de estas afirmaciones, entiendo que no se deben tomar en sentido estricto ya que no se pueden desligar totalmente los esfuerzos invertidos en que las asociaciones familiares pudieran participar en los procesos electorales y las Asociaciones Políticas creadas a partir de 1974. De esta forma, Tusell ${ }^{144}$ cuando afirma que la cuestión del asociacionismo, aunque no era de rango estrictamente constitucional, fue la cuestión política más importante o, incluso, la única importante a mediados de los sesenta y hasta la muerte de Franco, incluye dentro de este asunto tanto a la Ley de Asociaciones de Gobernación como al fallido Proyecto de la LACF.

En cierta forma es lo que se puede deducir de las afirmaciones de Fraga 145 en el Pleno del Consejo Nacional del 15 de diciembre de 1969. El ya ex ministro de Información, al referirse a la situación en que las asociaciones quedaban según la reestructuración de la SGM debatida en ese Pleno, afirmó:

«El texto que se nos propone suprime la DNA y no incluye ni una sola vez, en todo su articulado, la palabra asociación o asociaciones.(..) Los muchos hombres del Movimiento creemos que el proceso de desarrollo político y de apertura deben continuar, a todo trance; nos encontramos en una grave crisis de conciencia. Hablemos claro: los hombres que nos hemos batido por la representación familiar, por la libertad de las ideas y de su expresión; los que hemos presentado al país la Ley Orgánica como una etapa decisiva en la institucionalización y la apertura (no a la siniestra, sino hacia el futuro), tenemos que dejar constancia de que no hemos intentado engañar a nadie".

Como se ve, Fraga unía su antigua lucha por el asociacionismo familiar con la apertura política a través de las asociaciones.

También se puede deducir lo mismo de las afirmaciones que el consejero nacional por Alicante, Soler Llorca ${ }^{146}$, hizo en noviembre de 1968, en el seno del Consejo Nacional, momento en que se discutía el papel de las asociaciones dentro del Estatuto Orgánico del Movimiento; y no hay

144 Cfr. Tusell, J., Carrero, op. cit., pág. 286.

145 Citado en BadiA, Juan Ferrando, El Régimen de Franco, op. cit., pág. 177.

146 Citado en Badls, Juan Ferrando, El Régimen de Franco, op. cit., pág. 168. No cita la fuente. 
que olvidar que este Estatuto fue el origen del posterior Estatuto de Asociaciones Políticas ${ }^{147}$. Decía el consejero nacional:

«¿Por qué, si no todas al menos las asociaciones familiares, las que han de constituir los Consejos Locales y Provinciales, no pueden actuar electoralmente? ${ }^{148}(\ldots)$ ¿Y por qué no pueden intervenir en su elección asociaciones de diversas tendencias y simpatías por determinados candidatos? ¿Quién los va a proponer? ¿Los Gobernadores, el Ministerio de la Gobernación?"

Entiendo que esta cita apoya mi hipótesis acerca de que las asociaciones familiares estaban directamente relacionadas con las pretensiones de que en un futuro se crearan las asociaciones políticas.

Pero más que en las citas ya señaladas, creo que la relación entre las pretensiones de la LACF y el Estatuto de Asociaciones Políticas, habría que buscarlas en sus articulados. Ambas leyes pretendían abrir un cauce de representación a través de las asociaciones y la denominación era lo de menos. En todo caso, si existían diferencias en cuanto a su importancia, éstas beneficiarían a la LACF en detrimento del Estatuto de Asociaciones Políticas, ya que de haberse aprobado la primera, las asociaciones familiares hubieran tenido una capacidad de actuar en la vida política que nunca hubieran podido ejercer las asociaciones políticas creadas a partir de 1974.

\section{CONCLUSIÓN}

Los falangistas y los llamados católicos lucharon con denuedo para promocionar las asociaciones familiares con un fin claramente político. Pretendían utilizar ese eufemismo con el fin de poder llevar a sus cuadros hasta los más altos puestos de la administración franquista. La falta de unión entre estas dos fuerzas políticas facilitó que la postura de Presidencia y Gobernación -totalmente opuestas a que las asociaciones familiares tuvieran capacidad de proponer candidatos- triunfara impidiendo la aprobación de la LACF. Es un futurible pensar que si católicos y falangistas se hubieran unido las asociaciones familiares hubieran abierto el régimen 0 por el contrario se habría producido una involución. Pero quizá sí sea posible adivinar que, de haber triunfado las tesis de los católicos, en especial la posición de Monseñor Olaechea, en el sentido de dejar participar en las elecciones a todo tipo de asociaciones legalmente constituidas, el régimen podría haber sufrido un proceso de cambio más rápido hacia la democra-

147 Cfr. López Rodó, Memorias: Años Decisivos, op. cit., pág. 372.

148 El subrayado es nuestro. 
cia. Por el contrario, es posible que de haber triunfado las tesis de Solis y de Jordana de Pozas, en el sentido de permitir que únicamente los falangistas pudieran llegar a través de elecciones a los innumerables cargos previstos en la LACF, se hubiera producido una involución.

Entiendo que hubo una estrecha relación de fondo entre los fallidos proyectos de asociaciones familiares y el Estatuto de Asociaciones Políticas. EI complicado lenguaje utilizado por la dictadura, con el fin de dar consistencia doctrinal a los cambios que necesariamente se debian introducir ante la presión interna y externa, fue siempre muy ambiguo; y si a las asociaciones familiares no se les quiso dar el nombre de "políticas", no fue por que su finalidad no lo fuera, sino simplemente por «necesidades» del léxico del Estado Autoritario para ocultar lo evidente. Por eso la elaboración del Estatuto de Asociaciones Políticas, aprobado finalmente en 1974, no se puede desligar del intento realizado con el fin de que las asociaciones de cabezas de familia pudiesen promocionar hombres hacia la política. Éstas fueron las que permitieron, tras varios lustros de lucha, abrir el camino para las Asociaciones Políticas encuadradas dentro del Movimiento.

Con el Estatuto de Asociaciones, el Movimiento-Organización había conseguido, lo que llevaba decenios buscando: que las asociaciones, salidas de su seno, y fiscalizadas por él, pudiesen concurrir a todo tipo de elecciones en el ámbito local, provincial y nacional. Es cierto que ninguna Federación Provincial de Asociaciones Familiares se acogió a esta nueva posibilidad, pero esto refuerza la hipótesis de que lo que se deseaba no era potenciar el movimiento familiarista, sino buscar unos cauces más amplios de participación. Una vez que se percibía en el horizonte cercano la posibilidad de crear asociaciones con verdadero significado político, las asociaciones familiares quedaron olvidadas como un instrumento inservible.

A pesar del enorme esfuerzo invertido durante cerca de dos décadas para crear unas asociaciones capaces de promocionar políticos a los órganos representativos del país, los frutos concretos fueron escasos. Pocos meses después de aprobado el Estatuto de Asociaciones Políticas y el Decreto que lo regularía, moría Franco, y ningún tipo de elecciones se celebraron; por lo que, después de tanta lucha, las asociaciones no pudieron participar en ningún acontecimiento electoral.

Otra cuestión muy distinta es si esa intensa lucha sirvió para crear una conciencia solectiva en favor de la democracia. $Y$ aunque podríamos sugerir que sí, que la enorme repercusión que tuvo en la prensa el tema asociativo debió afectar positivamente en ese aspecto, es una pregunta que escapa a este estudio y a la metodología utilizada. 